NBER WORKING PAPER SERIES

\title{
WELFARE PROGRAMS AND LABOR SUPPLY
}

\author{
Robert Moffitt
}

Working Paper 9168

http://www.nber.org/papers/w9168

\author{
NATIONAL BUREAU OF ECONOMIC RESEARCH \\ 1050 Massachusetts Avenue \\ Cambridge, MA 02138 \\ September 2002
}

This paper is forthcoming in the Handbook of Public Economics. The author would like to than the participants of a Handbook conference in Berkeley, December 1-2, 2000, for comments, and Kara Levine for SIPP tabulations. The views expressed herein are those of the authors and not necessarily those of the National Bureau of Economic Research.

(C) 2002 by Robert Moffitt. All rights reserved. Short sections of text, not to exceed two paragraphs, may be quoted without explicit permission provided that full credit, including $\mathbb{C}$ notice, is given to the source. 
Welfare Programs and Labor Supply

Robert Moffitt

NBER Working Paper No. 9168

September 2002

JEL No. I13, J2

\title{
$\underline{\text { ABSTRACT }}$
}

The labor supply and other work incentive effects of welfare programs have long been a central concern in economic research. Work has also been an increasing focus of policy reforms in the U.S., culminating with a number of major policy changes in the 1990s whose intent was to increase employment and earnings levels of welfare recipients and other disadvantaged individuals. This paper reviews the economic research on this topic, covering both the theoretical models that have been developed as well as the empirical findings from econometric studies of the effects of existing welfare programs on labor supply.

\author{
Robert Moffitt \\ Department of Economics \\ John Hopkins University \\ 3400 N. Charles St. \\ Baltimore, MD 21218 \\ and NBER \\ moffitt@jhu.edu
}




\section{Table of Contents}

Introduction

I. Policy and Institutional Background

II. Theoretical Models and Issues

1. Introduction

2. The Basic Static Model

3. Dynamics

4. Work Requirements and Tagging Models

5. Wage and Earnings Subsidies

6. In-Kind Transfers

III. Empirical Evidence

1. Introduction

2. Pre-1995 Evidence

3. Post-1995 Structural Estimates

4. Post-1995 Reduced Form Policy Impact Estimates

IV. Summary 
The work incentives of programs which provide means-tested transfer benefits to the lowincome population has been a subject of increasing concern to voters and policy-makers in the U.S. Interest in work incentives first arose in the 1960s, when caseloads in the Aid to Families with Dependent Children (AFDC) program rose dramatically, and Congress lowered the tax rate on earnings in the program to encourage work. Increased interest in encouraging work among welfare recipients gradually grew in the 1970s and 1980s, with a shift in focus toward work requirements rather than lowered tax rates. In the 1990s, major new policy developments occurred whose focus was on increasing work, including 1996 legislation introducing major new work requirements into the AFDC program as well as the expansion of the Earned Income Tax Credit (EITC), an earnings subsidy program. Increased interest in encouraging work simultaneously has occurred in disability programs and the Food Stamp program. Similar reforms have developed in Europe, particularly in the United Kingdom with the recent introduction of the Working Families Tax Credit and with the welfare reform there termed the "New Deal."

Research on work and labor supply issues related to welfare reform has also long been the subject of attention by economists. In the 1960s, both James Tobin and Milton Friedman noted that the 100 percent marginal tax rates which were, at that time, imposed by some welfare programs discouraged work and that a negative income tax (NIT) with tax rates less than 100 percent was one solution (Friedman, 1962; Tobin, 1965). The NIT is now a staple of undergraduate textbooks. The economics profession conducted an enormous amount of research on the NIT in the 1970s, with much of the focus on the development of new econometric 
techniques for the analysis of work incentives, as well as a focus on the analysis of several random-assignment experimental tests of a negative income tax. After something of a research lull in the late 1970s and 1980s, there has been a resurgence of research interest in the 1990s in these issues which is still underway. Econometric methods have shifted toward more reduced form methods which make identification more transparent but whose results are less convenient for generalizability than the older structural methods. Much of the analysis has likewise shifted from the estimation of underlying models of behavior to the impact estimation of specific programmatic reforms.

\section{U.S. Policy and Institutional Background}

Table 1 shows some of the major welfare programs in the U.S. and their characteristics relevant to labor supply--who is eligible, the form of assistance, average transfer amounts, and marginal tax rates. The most well-known cash program, the Temporary Assistance for Needy Families (TANF) program, provides benefits primarily to single mothers and their children; the Supplemental Security Income (SSI) program serves low income aged, blind, and disabled individuals and families; the Earned Income Tax Credit (EITC) serves only those with positive earnings, albeit all individuals and families in that category; child care programs likewise serve only those who are working and with children; and the Medicaid program serves the aged and disabled as well as single mothers and their children, the latter overlapping heavily with the TANF population. Only the Food Stamp program and housing programs are universal in eligibility (aside from low income and assets), and even the latter is unique because it is rationed in quantity and hence not universally eligible in that sense. That leaves the Food Stamp program 
as the only truly universal means-tested transfer programs in the U.S.

This categorization of the population raises two issues. One is whether individuals can alter their eligibility status and change their labor supply in the process by making themselves eligible for a higher level of benefits. In some cases this might be desirable, as in the case of the EITC or child care where individuals might increase their labor supply to make themselves eligible for subsidies, while in other cases it might not be, as in the case of TANF or Medicaid where individuals (primarily women) might take actions to become, or remain, single mothers in order to retain eligibility for benefits, in most cases reducing their labor supply in the process. ${ }^{1}$ A second issue is whether, even if eligibility status is unalterable or at least alterable but exogenous to labor supply, the set of eligibility categories, benefit levels, and marginal tax rates assigned to the different groups in the population makes sense from a normative point of view. Answering this question requires a framework to assess normative issues and will not be discussed in this review, although it is a key design issue for the transfer system as a whole.

The form of assistance varies as well, from cash to in-kind transfers for food, medical care, housing, and child care. This is a particular feature of the U.S. system not present in some European countries, where there are no specific food programs and where health care is more typically covered by a universal program. The labor supply effects of in-kind transfers differ from those of cash transfers because they subsidize a good which may be a complement or substitute for leisure, and because in-kind transfers typically provide minimum or fixed quantities of the good in question and hence have the potential to constrain the consumption choices of the

${ }^{1}$ In all cases, of course, because benefits are only eligible for those with incomes below specified amounts, there is a labor supply disincentive. This is the standard labor supply effect to be discussed in Section II below. 
family. What evidence there is on the cash-equivalent value of in-kind transfers suggest that Food Stamps are very nearly equivalent to cash while Medicaid, housing, and child care are not (Smeeding, 1982).

Expenditures vary tremendously across programs, with Medicaid being the dominant program in this respect. However, the bulk of Medicaid expenditures go for the aged and disabled; single mothers and their children, the group of most research focus in the literature, constitute only a little over 10 percent of total Medicaid expenditures. Among the other programs, most are in the same general range except for child care, which is considerably smaller. The expenditures shown in Table 1 have changed dramatically over the last three decades, as TANF expenditures (equal to Aid to Families with Dependent Children, AFDC, prior to 1996) have declined from the largest in the late 1960s to one of the smallest today; as Food Stamps and Medicaid have grown, particularly the latter; and as the EITC and SSI expenditures have mushroomed (for more discussion of the history, see Moffitt (2001b)).

The last two columns in the table, showing average expenditures per family of 3 (a rough measure of benefits) and the marginal tax rate, give some indication of the magnitudes of income and substitution effects on labor supply, respectively. Medicaid has the largest average benefits but, again, are much smaller for a family of three consisting of a single mother and two children, which are approximately $\$ 427 .^{2}$ This makes SSI the largest average benefit program, perhaps not surprisingly since it serves a population which is capable of much less labor supply than the eligible populations for the other programs. Transfers for in-kind programs are generally smaller

2 This estimate equals the average expenditure per adult plus two times the average expenditure per child. It is larger than the amount for many single-mother Medicaid families off TANF, for whom only the children are eligible. 
than those for TANF, necessarily because they are intended to subsidize only part of consumption. An exception is the child care block grant program, although benefits in this program are poorly measured. The EITC, despite its relative high expenditure level, has, on average, very low benefits because its recipient base is so large. As for absolute amounts, the TANF, Food Stamps, and housing programs (ignoring child care) are sizable relative to fulltime minimum wage work of $\$ 893$ per month.

The marginal tax rates (MTRs) in the programs vary greatly. Those in the TANF program are now set by the states, and range from 0 to 100 percent (a zero percent MTR is possible only if the state imposes a maximum income level, which by itself imposes a cliff, or notch, in the benefit schedule). SSI imposes a 50 percent rate, Food Stamps imposes a 30 percent MTR, and public housing and Section 8 programs typically impose double MTRS, one on income net of deductions and one on gross income, ranging from 10 to 30 percent. The Medicaid program is the most extreme form of a cliff, or notch, program, which is available in its entirety (i.e., full subsidized care) until eligibility is ended--such as income exceeding a fixed amount. $^{3}$ The EITC is an earnings subsidy program which has negative MTRs as low as $-40 \%$ in its initial subsidy range and positive MTRS up to 21 percent in its phaseout range.

Virtually all of these rates are the same as they were when the program was created, with occasional important exceptions. The MTR in the TANF-AFDC program was 100 percent from its inception in 1935 to 1969 , when it was lowered to 67 percent; the MTR was raised back to 100 percent in 1981, where it remained until the 1996, when states were given freedom to set it at

${ }^{3}$ Medicaid has many different subprograms and a few currently require copayments, but they are the exception. 
their discretion. ${ }^{4}$ The EITC rates were increased in 1993 as well.

Employment rates in transfer programs generally vary with MTRs in the direction one should expect. In TANF, the average employment rate is currently approximately 30 percent, and is higher in those states with lower MTRs. Prior to 1996, when MTRs were closer to 100 percent, employment rates among AFDC recipients were approximately 9 percent. As will be discussed below, this relationship does not prove that there is an effect of MTRs on labor supply because a lower MTR has a higher "breakeven" level of hours-worked (i.e., the level at which eligibility ends) and thus more workers are eligible in that case. But it does show that the MTRs are actually enforced and do affect the numbers of recipients combining work and welfare. The employment rate in SSI is only 6.7 percent, no doubt reflecting the high rates of disability in the program. Food Stamp employment rates are 24 percent.

The actual MTRs in most programs differ in significant ways from the "nominal" MTRs shown in Table 1, complicating the picture. Virtually all have exemption amounts of earnings, below which benefits are not reduced and hence the MTR is zero. The TANF program, Food Stamps, Medicaid, and child care programs also all have maximum income limits that create notches, as benefits and eligibility go to zero for earnings that cause income to exceed those levels. In the TANF program, states are allowed to reduce calculated benefits by a fixed percentage, thereby reducing the MTR by that percent, as well as putting maximums on the benefit, which effectively creates a region of zero MTR. Most programs also allow deductions for work-related expenses and others for consumption items like housing or rental costs, which

${ }^{4}$ Under so-called waiver programs, states began to be allowed to set their MTR in the early 1990s. See Moffitt (2001a) for a detailed discussion. 
vary to some degree with income and hence lower the effective MTR. ${ }^{5}$ A further wrinkle in some programs, such as TANF and SSI, is that a different MTR is applied at initial application for the program as is applied thereafter. In most cases a 100\% MTR is applied at eligibility--that is, earnings are counted directly against the benefit--and then the lower, nominal MTR shown in Table 1 is applied after eligibility is established and recipiency has begun. These types of rules are designed to discourage entry into the program by workers. Their theoretical effects will be discussed below.

The MTRs may be considerably higher for families participating in more than one program, for the individual MTRs may add up to a considerably higher cumulative MTR. Table 2 shows multiple benefit receipt among nonelderly single mother families in 1997, excluding the EITC and child care programs. Around 16 percent of all single mothers received AFDC, Medicaid and Food Stamps and possibly one other program. About 32 percent of all single mothers who receive benefits from any program at all are in this multiple receipt category; thus about a third of all welfare recipients in this group have significant multiple benefit receipt. This is thus the major multiple recipient category among the programs listed inTable 1.

The cumulative MTR for families receiving these three benefits is not as high as might be thought, however. The MTR for Medicaid is zero until the eligibility point for AFDC is reached (Medicaid eligibility is automatic with AFDC receipt). Also, the Food Stamp program includes AFDC benefits as income. As a result, the cumulative MTR for TANF and Food Stamps

${ }^{5}$ Work-related expense deductions are somewhat ambiguous because, if they do reflect true costs of working, they do not lower the MTR if the latter were calculated on net income in the first place. But the deductions vary considerable from state to state, from program to program, and over time, and are unlikely to represent true costs of working. 
combined is $[t+.3(1-t)]$ where $t$ is the TANF MTR. Prior to 1996 , when $t=1.0$, the cumulative MTR was thus simply 1.0, not 1.3.

Cumulative MTRs after 1996 are shown in Table 3 for 12 states. The income calculations include the EITC and positive tax payments as well as TANF and Food Stamps, but not Medicaid. In the absence of the EITC, moving from 0 hours to part time hours at the minimum wage results in MTRs ranging from 34 percent to 71 percent. While these rates are less than 100 percent, they are not low by most standards (e.g., the positive income tax faced by most U.S. families). Moving from part time work to full time work results sometimes in higher MTRs and sometimes in lower ones, depending on the state. Higher MTRs typically occur when the individual hits the TANF income eligibility cliff and loses all benefits, while lower MTRs typically occur when the individual hits that limit in the neighborhood of part-time hours, implying that earnings obtained by moving to full-time work are taxed at lower, nonwelfare rates. Moving from minimum wage to $\$ 9 /$ hour at full time generally results in somewhat lower MTRs because usually the individual is off welfare by that point and hence only the nonwelfare rates almost always apply. The nonconvex budget set created by this pattern of rising then falling marginal rates tends to drive labor supply decisions to either extreme (i.e., either down to part-time work and up to an earnings level considerably above eligibility), a result to be shown formally below. ${ }^{6}$

The EITC has drastic effects on these rates. ${ }^{7}$ Moving from no work to part-time work or

6 Adding Medicaid into the calculation would increase MTRs greatly in the second and third categories, where TANF eligibility is lost.

${ }^{7}$ After 1996 states are allowed to count the EITC in TANF income calculations but they generally do not do so. 
from part-time work to full time work, rates are lowered by as much as 40 percent, which is the largest subsidy rate in the EITC. The resulting MTRs are quite low, no more than 30 percent in the first case and 47 percent in the second. However, when moving from the minimum wage to \$9/hour at full time work, the EITC actually increases the cumulative MTR because the individual is in the phaseout range of the EITC by that point. Cumulative MTRs are never lower than 55 percent and are often in the 80-percent range when moving to this higher earnings level. Thus the EITC effectively convexifies the budget set, which should be expected to drive labor supply decisions toward the middle point. Thus there is an incentive to increase earnings from no work to full time work but also to decrease earnings from high-wage work to lower-wage work, with expected ambiguous effects on labor supply (see below).

Finally, it should be emphasized that the benefit formula is not the only source of labor supply incentives in many U.S. transfer programs, for work requirements have an additional, perhaps stronger, effect. In the TANF program, recipients are required to work some minimum number of hours (usually 20 per week or more) after some minimum stay on the welfare rolls, and sanctions (i.e., benefit reductions) are applied vigorously if recipients fail to meet the requirements. The Food Stamp program also has work requirements for all recipients and particularly strong requirements for non-disabled single individuals. Models of work requirements will be considered below.

\section{Theoretical Models and Issues}

Introduction. The basic static model of labor supply familiar to undergraduate textbooks 
has been the workhorse of the literature on work incentives of welfare programs for over thirty years. Despite the clear importance of dynamics, human capital, job search, and other considerations in the study of the effects of welfare programs, the endurance of the static model is testimony to its usefulness for the analysis of a wide range of types of welfare program alternatives and the analysis of the comparative statics of an equally wide range of effects of simple changes in program parameters. Its ease of graphical analysis increases its usefulness as an analytic tool.

Relative to the same model used for the work incentives of income and payroll taxes, the welfare application has some unique features, however. One is that the means-testing inherent in a welfare program necessarily creates a nonconvexity in the budget set somewhere over the range of earnings, at the very least at the point where income rises to the point of ineligibility. Changes in welfare reform parameters inevitably either change this eligibility point or change the incentives for individuals to locate above or below it, and this sets off work incentives which greatly complicate the analysis relative to that of income and payroll taxes. A related unique feature of welfare program analysis is that participation in welfare itself is a choice variable, partly because of the decision to locate above or below the eligibility point but also, it turns out, because even some of those whose income is below that point choose not to go onto welfare. This also adds some complexity to the model and to the analysis of labor supply effects.

These unique features have important ramifications for normative questions concerning optimal design of welfare programs. It turns out that almost all changes in welfare program parameters have labor supply effects that differ for different individuals in the distribution, and the desirability of implementing those changes requires a social welfare function or some other 
public choice mechanism which explicitly or implicitly assigns weights to distributional objectives. Almost no program reforms have unambiguously desirable labor supply effects on their own. Even a program as well-known and popular among economists as the negative income tax shares this feature, and its normative advantages in terms of labor supply are quite questionable without such an analysis. While the exposition presented below will stick fairly closely to positive analysis, normative issues will necessarily be referred to in appropriate places.

A final feature of the welfare model also relating to optimal design arises from the abovenoted feature that welfare program participation is a choice and that some choose, voluntarily, not to participate. This necessarily self-categorizes the eligible population into those on welfare and those not, which implies that modifications of the welfare system in the form of adding new programs--e.g., for food, housing, medical assistance, or job training--must confront how those programs should be made available to those on the initial welfare program (e.g., cash) and those not. Both equity considerations play a role in that decision as well as efficiency ones, for if the different programs are at all tied together, incentives to join the various programs will be altered. A universalist policy which keeps all programs separate and makes all of them available to all of the low-income population is one extreme, but one that has been rarely chosen by U.S. policymakers.

Basic Static Model. The canonical static model of labor supply considers an individual with well-behaved preference function over hours of leisure (L) and consumption (C) which we denote as $\mathrm{U}(\mathrm{L}, \mathrm{C})$ and budget constraint $\mathrm{N}+\mathrm{W}(\mathrm{T}-\mathrm{L})=\mathrm{PC}$, where $\mathrm{N}$ is exogenous unearned income, $\mathrm{W}$ is the hourly wage rate, $\mathrm{P}$ is the price of consumption goods, and $\mathrm{T}$ is the total time available in the interval. With normalization by $\mathrm{P}$ we may relabel $\mathrm{C}$ as income, $\mathrm{Y}$. With hours 
of work defined as $\mathrm{H}=\mathrm{T}-\mathrm{L}$, we can equivalently consider a preference function $\mathrm{U}(\mathrm{H}, \mathrm{Y})$

maximized w.r.t. $\mathrm{N}+\mathrm{WH}=\mathrm{Y} . \quad$ A generic welfare program provides benefit $\mathrm{B}=\mathrm{G}-\mathrm{t}(\mathrm{WH}+\mathrm{N})$, where $\mathrm{G}$ is the guarantee amount given to those with zero income and $\mathrm{t}$ is the marginal tax rate. With benefits added into the budget constraint, we have $\mathrm{W}(1-\mathrm{t}) \mathrm{H}+\mathrm{G}-\mathrm{tN}=\mathrm{Y}$.

Figure 1 shows the familiar budget constraint so created as segment $\mathrm{CD}$, where the intercept with vertical distance $\mathrm{AC}$ represents $\mathrm{G}$ and where the slope of segment $\mathrm{CD}$ is $-\mathrm{W}(1-\mathrm{t})$. The nonwelfare constraint is $\mathrm{AE}$ with slope $-\mathrm{W}$ and intercept $\mathrm{N}$ (assumed to be zero for illustration). The arrows labeled 1 and 2 denote the two types of labor supply response to the creation of the welfare program, and both result in reductions in labor supply unambiguously.

The nonconvexity of the budget set clearly is a defining characteristics of Figure 1. It could be argued that individuals can convexify that constraint by moving on and off the program over time, thereby achieving an average hours of work and average income that lies above the constraint CDE. Put differently, they could "build" a constraint to bridge the nonconvexity. Ignoring preference discounting, higher utility could be gained in that way than by choosing a fixed hours along CDE. One theory of welfare turnover is that it is induced precisely by this feature of the constraint, explaining why many individuals alternate between not working at all and being on welfare with working and not being on welfare, treating the two as mutually exclusive alternatives.

The existence of nonparticipating eligibles as a complicating factor may be mentioned at this point. For virtually all welfare programs, some individuals are observed to locate on segment AD in Figure 1, in a location which would appear to be inferior to being on welfare. One rationalization for this behavior is to assume that being on welfare carries some disutility, 
possibly arising from the stigma of being on welfare (Moffitt, 1983). This can be modeled by inserting a welfare participation dummy, $\mathrm{P}$ (equal to 1 if on welfare and 0 if not) into the preference function as in $\mathrm{U}(\mathrm{H}, \mathrm{Y}, \mathrm{P})$, where $\mathrm{P}$ has negative marginal utility. With heterogeneity of preferences w.r.t. $\mathrm{P}$ across the population of a sufficiently wide range, some individuals will choose not to participate despite the income and leisure gains to doing so. An alternative rationalization is to assume that there are fixed costs of going onto welfare in the form of time, money, or "hassle" costs of complying with the myriad rules of welfare and requirements to visit the welfare office periodically. With heterogeneity of such costs across the population, and with a sufficiently wide range that for some individuals the costs will exceed the utility gains of welfare participation, some individuals will again choose not to go onto welfare. These two models are observationally equivalent without some further structure imposed on them or some actual data on stigma or participation costs. ${ }^{8}$

The labor supply implications of such nonparticipating eligibles are, at this stage, straightforward, for participation in welfare is more likely, the greater the utility gains from income and leisure, holding the stigma or fixed costs constant. Whether labor supply falls or rises upon joining the welfare program depends on the substitutability or complementarity of $\mathrm{P}$ and $\mathrm{L}$ in the preference function, but if $\mathrm{P}$ is separable then labor supply will fall, as illustrated in Figure 1 by the arrow 1 .

The most important two comparative statics of the model are those involving the effects

8 One approach in the literature to the stigma model is to consider stigma to be a function of how many other families are on welfare. This sets up a social interactions model with interdependent choices in the population. See Besley and Coate (1992a), Lindbeck et al. (1999), and Nechbya (1999). 
of a change in $\mathrm{G}$ and a change in $\mathrm{t}$. Figure 2 illustrates the effect of an increase in $\mathrm{G}$. All three types of labor supply effects, shown by the three arrows, are negative. Note that the change in labor supply is not a measure of traditional pure income effects because those represented by arrows 2 and 3 experience substitution as well as income effects, though these operate in the same direction as the income effects. Not shown in the figure are the effects on nonparticipating eligibles, for some individuals will move from segment AD to C'D' because the utility gains will now outweigh the costs of participating.

A reduction in $\mathrm{t}$ is illustrated in Figure 3, where the pre-change constraint is shown to have $t=1.0$ (segment $C D$ ). Again, there are three types of response illustrated in the figure, but in this case the second two are opposite in sign to the first, resulting in an ambiguous net change in hours worked. The average change depends on the sizes of the different responses as well as the relative numbers of individuals at different initial points along the constraint. Those represented by arrow 2 are made newly eligible by the reduction in $t$ and hence reduce their labor supply whereas those represented by arrow 3 now find the higher benefits available over the positive hours range to be sufficiently great as to reduce labor supply to join the program. ${ }^{9}$ Because the region around points D and D' often fall in the part-time hours range, it can be said that this reform essentially subsidizes part time work.

Among other things, this result shows why the employment rates or hours of work of those on welfare may be correlated with the level of t even if there is no labor supply response.

9 Ashenfelter (1983) termed the arrow-2 response a "mechanical" change and the arrow-3 response a "behavioral" change. This interpretation is useful but is complicated by the presence of nonparticipating eligibles, some of whom in the range DD' will choose not to go onto the program despite the potential income and leisure gains. 
For example, if arrows 1 and 3 are zero and arrow 2 is vertical (i.e., labor supply does not change when going onto the program for these individuals), then employment rates and mean hours of work of those on welfare will rise after the reduction in t, but this is just a compositional effect resulting from the addition of a group of high-hours workers to the welfare rolls.

The implication of this analysis is that the negative income tax, and general reductions in t, do not necessarily increase average labor supply (Levy, 1979; Moffitt, 1992). A corollary of this result is that it is possible that 100 percent tax rates maximize average labor supply. However, the distributional impacts of the tax rate reduction must be considered. The reform does achieve its objective of encouraging the lowest-labor-supply individuals to work more, but at the cost of some labor supply reduction among higher-labor-supply individuals, many of whom are in the group termed the "working poor." Incomes are increased among the latter group (at least for those represented by arrow 2) as well, representing a shift in the income distributional impact of the welfare program away from the lowest-income individuals and toward somewhat higher-income individuals, at least in relative terms. ${ }^{10}$ Much of the policy debate over the desirability of a negative income tax and similar reforms revolves around the relative distributional weights assigned to the very poorest (sometimes called the "target efficiency" of the program) versus the "working poor," who receive no assistance in a $t=1.0$ program.

In the U.S. TANF program, states have tried at least two measures to avoid the labor supply reducing effects of $t$ reductions. One is to disallow the lower $t$ when considering initial

10 An expenditure-constant change in $\mathrm{G}$ and $\mathrm{t}$, for example, would rotate the segment $\mathrm{CD}$ ' in a direction increasing the slope, showing more clearly the existence of such a distributional shift. 
eligibility, and to allow the lower t only for those individuals who have established eligibility under the stricter standard. In a world without transactions costs, these barriers would have no effect and individuals who wished to locate in the region DD' in Figure 3 would simply reduce their labor supply to point $\mathrm{C}$ to become eligible and then increase their labor supply to the preferred point. ${ }^{11}$ With costs to entry and application, this process will be slowed but not eliminated. A second strategy by states is simply to impose an upper limit on income independent of the benefit formula, as illustrated in Figure 4. In that figure, the notch occurs at point D and the segment DD' is eliminated, discouraging workers above that point from coming onto the welfare program. However, some will still reduce their labor supply to point D in any case, and labor supply gains that might have been experienced by those initially on welfare who would have otherwise increased work into the DD' region are lost, so there is a cost to this approach. However, a number of states have taken this approach to its extreme by setting $\mathrm{t}=0$ at the same time as imposing such an eligibility limit.

Figure 4 also illustrates notch constraints in general, as occur in the Medicaid and other programs. The dotted line from D to D' represents the effect of removing the notch and allowing a gradual phaseout of benefits. This change has ambiguous effects on labor supply for the same reason that a general reduction in t does. While it is true that those initially at $\mathrm{D}$ are encouraged to work more (arrow 1), those represented by arrows 2 and 3 experience labor supply reductions. Thus the labor supply effects of eliminating welfare-program notches is ambiguous

11 Random shocks to labor supply would achieve the same result, e.g., if every individual has a probability $\mathrm{p}$ of being laid off or losing her job each period, after which labor supply can be freely chosen until the next layoff occurs, individuals will eventually end up at the global utility maximum regardless of the stricter eligibility rules. 
in sign.

A different method of providing work incentives is by increasing the rewards of being off welfare rather than on welfare. Whereas the reduction in $\mathrm{t}$ attempts to provide incentives by encouraging individuals to combine welfare and work, increasing subsidies for those who are off welfare and work could seemingly provide greater labor supply increases. Figure 5 illustrates one real-world case of such a reform, in this case one in which Medicaid is offered to lowincome families off welfare up to some maximum income point (the dotted line C'D'). An increase in child support income off welfare has similar effects, but without the notch. Arrow 1 represents the labor supply increases generated by this reform as some individuals move off welfare and receive Medicaid while off. However, labor supply reductions also occur, as shown by arrows 2,3, and 4 (arrow 4 arises as some of those who did not want to participate in the initial welfare program find Medicaid acceptable). Thus the labor supply effects of this reform are again ambiguous in sign.

Of course, providing a new form of welfare "off welfare" is just a matter of semantics, for in essence this reform just adds another layer onto the initial welfare system. Ignoring the possible responses of nonparticipating eligibles or different stigma effects of the programs, the effect of this reform is no different than simply extending Medicaid eligibility for those initially on welfare up to point D', which is very similar to a reduction in t. Alternatively, simply combining the two programs and having one program with the constraint CDD' would be equivalent. The popularity of some of these reforms to the general public appears instead to be based on the idea that Medicaid, child support, and other forms of welfare represented by the constraint C'D' are preferable to cash welfare possibly represented by CD. But that requires 
bringing voter preferences into the model, which has not been done here. In the recipientoriented model used here, there is no important difference between "on welfare" and "off welfare" reforms if they are all essentially welfare, and it is merely a matter of government form whether assistance is provided in one program or multiple programs so long as the eligibility groups are identical. The fundamental design issue of how to construct the overall constraint, where assistance should be given across the income and labor supply distribution, and where labor supply incentives and disincentives are preferred to occur, remains and requires addressing the same distributional questions already discussed.

Dynamics. We shall consider three separate topics in this section: (1) welfare program effects on labor supply in a life cycle context, (2) effects of welfare programs on human capital investment, (3) effects of welfare-based human capital investment programs, and (4) time limits on welfare receipt. There has been relatively little research on these issues so this section will be necessarily briefer than the last.

Life cycle labor supply models are generally considered to be separable in order to apply two-stage budgeting techniques familiar from the literature on consumption (Blundell and MaCurdy, 1999). If an individual is on welfare in all periods, the analysis of labor supply effects of welfare programs is simple because those programs just reduce the net wage and increase nonlabor income. This leads to reductions in labor supply in all periods and to intertemporal wealth effects which also reduce labor supply. If the individual is on welfare in some periods and off in others, this also can be accounted for within the framework by the use of virtual income and virtual net wage formulations (Blundell and MaCurdy). Intertemporal asset allocations can be, as before, separated from the within-period decisions, and the latter are 
essentially the same as those in the static model with an adjustment in full income to take account of the asset flows. Thus the net result of these models in the life cycle labor supply literature is that there is little if any alteration in the basic labor supply effects found in the static model.

Two different types of effects are possible, however. One is the possibility of "building" a convexified constraint over the nonconvex budget set by moving on and off the program in different periods, as mentioned previously. This case has not been analyzed in the literature. Another is the effect of the income floor in transfer programs, which reduces precautionary saving and hence labor supply, as noted by Hubbard et al. (1995).

Effects of welfare programs on human capital investment have also been little studied. ${ }^{12}$ Kesselman (1976) analyzed the effects of a welfare program on human capital, assuming that the individual was on welfare both before and after the human capital investment decision. Under this assumption, the effect of welfare programs is to reduce the incentive for human capital investment because both the opportunity cost of time changes from $\mathrm{W}$ to $\mathrm{W}(1-\mathrm{t})$ and the return to investment changes from $\mathrm{W}$ to $\mathrm{W}(1-\mathrm{t})$; thus the rate of return is simply reduced to (1-t) of what it is in the absence of the program. This result is identical to that of the effect of a proportional income tax on human capital investment in an equally simple model. Income effects play no role, as is typical in human capital investments which assume perfect capital markets.

However, an investment in human capital which has a sufficiently high return as to move the individual above the income eligibility point and hence off welfare has a higher return than this, because the return, at the margin, remains $\mathrm{W}$ rather than $\mathrm{W}(1-\mathrm{t})$. Thus human capital

12 See Miller and Sanders (1997) for an exception. 
investment is encouraged relative to what it would be in the absence of the program. This is entirely the result of the nonconvexity of the budget set, which leads to a type of increasing returns to investment.

The effects of human capital investment programs, or job training programs, for welfare recipients has been discussed by Moffitt (2001a). The relevant case is that in which a recipient is required to undergo training as a condition of welfare receipt, and thus human capital investment becomes a type of work requirement. In this case the net present value of the investment opportunity becomes part of the welfare package. In a two-period model, that net present value is

$$
\begin{aligned}
\mathrm{NPV}=-\mathrm{W}_{1}(1-\mathrm{t}) \mathrm{I}+\frac{1}{1+\mathrm{r}}\left\{\mathrm{P}_{2}\left[\left(\mathrm{~W}_{2}-\mathrm{W}_{1}\right)(1-\mathrm{t}) \mathrm{H}_{2}\right]\right. \\
\left.+\left(1-\mathrm{P}_{2}\right)\left[\left(\mathrm{W}_{2}-\mathrm{W}_{1}\right) \mathrm{H}_{2}-\left(\mathrm{G}-\mathrm{tW}_{1} \mathrm{H}_{2}\right)\right]\right\}
\end{aligned}
$$

where $\mathrm{W}_{1}$ is the wage if the recipient were not to undergo the training program, $\mathrm{W}_{2}$ is the (higher) wage in period two if she does, $\mathrm{I}$ is the amount of investment time required in period one (assumed to come out of work time rather than leisure), $\mathrm{H}_{2}$ is hours worked in period 2, and $\mathrm{P}_{2}$ is a welfare participation dummy in period two if the recipient undergoes the program. ${ }^{13}$ The investment cost is represented by the first term and the return by the term in curly brackets, which depends on whether the individual is still on welfare after the wage increase. If not, the return is equal to the earnings gain minus the welfare benefit lost. If this net present value is positive, the welfare program is enhanced in value because it offers a training program with a positive return which is not available elsewhere, leading to an increase in welfare participation;

13 The change in $\mathrm{H}_{2}$ resulting from the increase in the wage is ignored for simplicity. 
but if it is negative, the value of the welfare program is enhanced and welfare participation will decline.

If the program is voluntary for welfare recipients, then the value of welfare cannot decline and welfare participation will ambiguously increase. Both of these cases illustrate the issue of tied transfers discussed previously, for a universal human capital program available to all low income individuals would not have an effect on the welfare caseload as it does in these cases, when the program is only offered, or mandated, to welfare recipients.

Time limits on welfare receipt have dynamic effects that are more interesting than their long run static effects. The long run static effects of time limits are simply to eliminate welfare completely, and this should be expected to increase labor supply for the same reasons that welfare decreases labor supply in the first place. Supporters of time limits sometimes argue that mandatory human capital investment programs of the type just discussed would, if required during all available years of welfare receipt, increase potential wages enough that a former welfare recipient could be better off after the end of the time limit by working than he or she would have been on welfare. The empirical evidence on the rates of return to these programs does not support this conjecture, at least on average (see below). Instead, time limits are best interpreted as simply a desire to reduce redistribution. ${ }^{14}$

There are two types of dynamics effects that could arise from the presence of time limits.

14 A more interesting question is why time limits would be preferred by the voters to simple reductions in benefit levels. This preference is probably based on the assumption that individuals experience a finite number of discrete negative shocks over their lifetimes and that full support should be given during those periods but not during others. A lower but permanent benefit level would simply lower the amount of support given during the periods during which negative shocks occur. 
One would occur if individuals on welfare anticipate the approach of the limit and begin to leave welfare and accept job offers at an increasing rate as the limit nears. This behavior has been noted for unemployment insurance recipients approaching the point at which their benefits will be exhausted (Moffitt, 1985). In the UI case, this behavior is generally explained by the randomness of wage offers and the desire to accept an attractive offer when it arrives even if it does so somewhat in advance of the benefit exhaustion date. The same may apply for welfare recipients approaching a time limit. The result is that labor supply will begin to increase in advance of the actual time limit, and that labor supply effects would be observed to occur even for those who do not actually exhaust their benefits. ${ }^{15}$

A second response can occur if recipients "bank" their benefits by going off the rolls during good (labor market) times and saving their benefits for bad times (downturn in labor market, unexpected negative income shock, etc). This result again requires the presence of uncertainty in future wage offers. A simple artificial model proves the possibility of this response. Suppose that the lifetime consists of two periods and that welfare can only be received in one of them. The per-period utility function is $\mathrm{Y}-\alpha \mathrm{H}$ where $\mathrm{Y}$ is income and $\mathrm{H}$ is a dummy equal to 1 if the individual works and 0 if not. Let $\mathrm{B}$ be the welfare benefit and suppose that an individual has a per-period probability $\mathrm{p}$ of a wage draw $\mathrm{W}>0$ and probability 1-p of a wage draw $\mathrm{W}=0$. To make the comparison stark, let the positive wage draw equal $\mathrm{B}$. Then, in the absence of any time limit, the individual will be on welfare both periods regardless of the wage draw because even if a positive wage is drawn, the disutility from working will make

${ }^{15}$ See Gottschalk (1988) for a model of the effect of welfare programs on job search and Krueger and Meyers (in this volume) for a review of the unemployment insurance literature. 
welfare participation the preferred choice. But with a time limit, an individual who has drawn a positive wage of B in the first period and is choosing whether to work and stay off welfare vs going onto welfare and using up her entitlement compares utility for these two alternatives, which are, respectively

$$
\begin{aligned}
& B-\alpha+\beta[p B+(1-p) B] \quad \text { if work in period } 1 \\
& B \quad+\beta[p(B-\alpha)+(1-p) 0] \quad \text { if go onto welfare in period } 1
\end{aligned}
$$

where $\beta<1$ is the discount rate. The value of working in period 1 is therefore

$$
-\alpha(1-\beta p)+\beta B(1-p)
$$

If $\mathrm{p}<1$ then this quantity can be positive if the second term is larger than the first. Thus the person will choose to work today and go onto welfare tomorrow even though the myopic decision today would be to go onto welfare.

Work Requirements and Tagging Models. In several U.S. welfare programs, work requirements have become an alternative means by which labor supply of welfare recipients can be increased. Figure 6 shows the effect of such a program which requires $\mathrm{H}_{\min }$ hours of work on the part of the recipient. This eliminates the portion of the budget BC. Arrows 1 and 2 show possible responses, both of which lead to increases in hours of work. A work requirement, therefore, unambiguously increases labor supply. This should not be surprising because it is equivalent to eliminating welfare altogether over a certain hours range, and welfare is known to 
decrease labor supply unambiguously.

This favorable result is often contrasted by policy-makers with a reduction in $\mathrm{t}$, which yields ambiguous effects on labor supply. However, the comparison is not appropriate because the conventional welfare program attempts to provide support to those who have sufficiently low wages (perhaps because of health reasons or very young children) that their hours of work are low or zero whereas a work requirement system provides no such support. Work requirement programs instead must necessarily be accompanied by a categorization of the welfare population into those who can work, who are given the budget constraint shown in Figure 6 with a minimum hours requirement, and those who cannot work, who are give support even at zero hours. Work requirements also stand in contrast to the idea of a negative income tax, which attempts to provide income support to those with low wages at the same time as providing some work incentives (through a reduced t). The favorable labor supply effects of work requirements are entirely dependent on the ability to adequately categorize the welfare population into the two groups.

There is a literature on tagging and related issues which considers the properties and desirability of these types of categorical systems. Akerlof (1978) showed that if individuals can be "tagged" as nonemployable, they can be given a greater $\mathrm{G}$ and lower $\mathrm{t}$ than they could under a noncategorical negative income tax. He, and others in this literature, directly dealt with the incentive problem to change categories by requiring that an incentive compatibility constraint be set that would discourage such behavior. Parsons (1996) extended the Akerlof model to consider what he termed "two-sided" error, meaning that not only are some of the untagged individuals truly nonemployable, but some of the tagged individuals are in fact employable. 
This leads to an optimal structure in which a positive $\mathrm{G}$ is given to both tagged and untagged individuals, but a higher $\mathrm{G}$ and lower $\mathrm{t}$ is given to the tagged group. More direct consideration of workfare as an alternative is considered in other papers. For example, Besley and Coate (1992b, 1995) showed that, under a different optimization criterion, workfare can be used as a screening device to ensure that higher-wage individuals do not take advantage of the program. In this rather different justification for work requirements, all recipients must undergo the cost of complying with work requirements, but benefits can be higher because high-wage individuals have been screened out. ${ }^{16}$

The literature surrounding the negative income tax in the late 1960s and early 1970s emphasized the difficulties in tagging. It was generally argued that the administrative difficulty in assigning recipients to categories is too great for work requirements to avoid large error. It was also argued that work requirements would inevitably end up giving individual caseworkers in local welfare offices great discretion in deciding who is able to work and who is not, and that this would create an unacceptable level of inequitable treatment across individuals who are observationally identical (Barth and Greenberg (1971), Browning (1975), Lurie (1975)).

Wage and Earnings Subsidies. Wage and earnings subsidy programs have been discussed for many years as a means to increase labor supply incentives. In a wage subsidy, a government subsidy increases the hourly wage of an individual by $[\alpha-\beta \mathrm{W}]$, where $\mathrm{W}$ is the individual's initial wage and $\beta<1$. The resulting remuneration per hour for an individual is $\alpha+(1-\beta) \mathrm{W}$. The subsidy declines as $\mathrm{W}$ rises and reaches zero at $\mathrm{W}=\alpha / \beta$. In an earnings

\footnotetext{
${ }^{16}$ For other papers in this literature, see Beaudry and Blackorby (1998), Chone and Laroque (2001), Cuff (2000), and Immonen et al. (1998).
} 
subsidy, an individual receive a subsidy $\mathrm{S}=\mathrm{sWH}$ for earnings up to some cutoff level $\mathrm{C}$, where $\mathrm{s}<1$, and after that cutoff level the subsidy is recalculated as $\mathrm{S}=\mathrm{sC}-\mathrm{r}(\mathrm{WH}-\mathrm{C})$, which declines at rate $\mathrm{r}$ for every dollar of earnings. The subsidy reaches zero at earnings equal to $[\mathrm{C}(\mathrm{s}-\mathrm{r}) / \mathrm{r}]$. The net wage up to $\mathrm{C}$ is $\mathrm{W}(1+\mathrm{s})$ while the net wage above $\mathrm{C}$ is $\mathrm{W}(1-\mathrm{r}){ }^{17}$

Figure 7 shows how both types of subsidy affect the budget constraint. The wage rate subsidy creates the budget constraint AC while the earnings subsidy creates the constraint ABD. The labor supply responses are indicated by the arrows. The response for the wage subsidy is represented by arrows 1 and 2. While those entering work from nonwork clearly increase labor supply, the income and substitution effects of those initially at positive hours go in opposite directions, leading to a change ambiguous in sign. However, most of the groups made eligible for these subsidies have forward-bending labor supply curves, so the impact of the subsidy is generally expected to be positive. The earnings subsidy has the same effect in low ranges but a negative effect in the higher ranges of earnings and hours worked, where the earnings subsidy is reduced. Arrows 3 and 4 both represent reductions in labor supply. The net effect of the subsidy is ambiguous in sign. As for the welfare programs discussed earlier, the distributional impact of the program is important because the positive and negative labor supply effects occur in different ranges.

A simple comparison of the wage and earnings subsidies in the Figure indicates that wage subsidies, because they do not have the taxback region $\mathrm{BD}$, are more likely to increase labor

\footnotetext{
${ }^{17}$ In some earnings subsidies, like the U.S. EITC, there is a flat range of earnings in the middle over which the subsidy stays at its maximum, before starting to decline. There is a large literature on wage and earnings subsidies dating from the 1960s and 1970s. For some of the early discussions, see Barth and Greenberg (1971), Garfinkel (1973), Kesselman (1969, 1973), and Zeckhauser, 1971.
} 
supply than earnings subsidies. However, the wage rate subsidy must nevertheless be phased out as the wage rises, and this creates a disincentive for human capital investment, job search, and other activities seeking higher wages. As it has turned out in the U.S., wage-rate subsidies have foundered in any case on the administrative difficulties of measuring hourly wages and basing a transfer on them. Many individuals are not paid by the hour, for example, and even those that are often have an agreement with the employer for a stipulated number of hours of work, making the contract closer to an earnings agreement than an hourly wage agreement. Further, a wage-rate subsidy creates opportunities for fraudulent collusion on the part of the employee and employer to set the pay in terms of earnings rather than wages and then to overstate hours of work, pushing the reported wage rate down and the subsidy up. Preventing manipulations of the reported hourly wage would be quite difficult. For this reason, earnings subsidies, which are administratively simpler to conduct, are more common, even though they, too, have some incentives for overreporting of earnings (Hotz and Scholz, forthcoming).

The goal of wage and earnings subsidies is explicitly to increase earnings and labor supply. A secondary goal--though a primary one to some voters and policy-makers--is to increase government support for the "working poor," roughly meaning those families and individuals with significant hours of work but still low earnings. An earnings subsidy can be designed so that the maximum subsidy at point B in Figure 7 is in the middle of the range of earnings that define that group. This is a purely distributional goal that, in principle, could be at odds with the goal of increasing labor supply, particularly if the labor supply disincentives in the taxback region are significant. As has been demonstrated in several programs already in this review, subsidizing one part of the hours or earnings distribution tends to draw individuals to that 
region from both above and below.

Earnings subsidies have also been proposed for those demographic groups who are eligible for an existing income transfer program, in the hopes that the earnings subsidy can counter the labor supply disincentives created by the tax rate of the welfare program. The combination of the two is illustrated in Figure 8, which is drawn on the assumption that the maximum earnings subsidy occurs at an hours level in excess of the hours level which ends the income transfer. ${ }^{18}$ Compared to the income-transfer-only, the addition of the earnings subsidy has the same mix of positive and negative labor supply effects as the pure earnings subsidy, leading to ambiguous effects on labor supply. However, labor supply incentives for initial welfare recipients are all positive (assuming forward-bending labor supply curves) and it is possible as well that those recipients may "leave welfare" in some cases. ${ }^{19}$ As illustrated in Table 3 discussed earlier, earnings subsidies have greatly reduced the cumulative marginal tax rate on earnings for welfare recipients, although they have also raised that rate at higher levels of earnings. This effect is clear from Figure 8.

The shift in Figure 8 is the same as that created by a reduction in $t$ in a welfare program at

${ }^{18}$ In the U.S., most welfare programs do not include the EITC as part of income. If they did, the effect of the earnings subsidy in pivoting the segment $\mathrm{CD}$ in Figure 8 around to $\mathrm{CF}$ would be much smaller. Indeed, if $\mathrm{t}=1.0$ in the welfare program, there would be no effect at all of the earnings subsidy on the slope of this segment if the earnings subsidy is included as income.

19 As noted previously in the discussion of the Medicaid expansions and child support programs, many policy makers and analysts regard earnings subsidies as "not welfare" because they are not stigmatizing to the recipient and are more highly valued by the voter. This discussion ignores those effects. If stigma is less for the earnings subsidy than for income transfers, it is also possible that an individual on welfare may move off the welfare rolls to segment AD in Figure 8 and receive only the earnings subsidy, becoming an eligible nonparticipant for welfare. 
point $\mathrm{F}$ and below and differs only above $\mathrm{F}$. The labor supply disincentives shown by arrow 4 are also the same as those created by the reduction in t. However, the labor supply disincentives represented by that arrow occur at a higher level of earnings than would occur from a reduction in t equivalent in magnitude to that created by segment $\mathrm{CF}$ (i.e., if $\mathrm{CF}$ were extended upward, as in the case of a t reduction). In this sense, the earnings subsidy simply pushes the labor supply disincentives further up the earnings and hours distribution than they would be under a reduction in t. Once again, the desirability of this shift depends on the distributional weights assigned to the groups in the population. On the other hand, if point $\mathrm{G}$ falls closer to point $\mathrm{F}$ than is shown in the figure, then there is little difference in an earnings subsidy addition and a reduction in $t$ in the first place.

The comparison of the program shown in Figure 8 with a reduction in $t$ in a welfare program is also complicated by the fact that public expenditures are almost surely higher for the Figure 8 earnings subsidy addition than by the reduction in $\mathrm{t}$, for subsidies are paid out at much higher earnings levels which are typically in much thicker regions of the income distribution. This makes it appear as though all individuals can be made better off and no one worse off. A fairer comparison would be an expenditure-constant comparison of an earnings subsidy addition versus a reduction in $\mathrm{t}$, for in that case the level of $\mathrm{G}$ would have to be lower at the time the earnings subsidy is introduced to reduce expenditures. This demonstrates more clearly that the earnings subsidy addition is a regressive program relative to a program which reduces $t$, for it shifts support, in relative terms, away from the worst-off families and individuals and toward those who are better off. This is the underlying reason for its favorable effects on labor supply.

Finally, Figure 9 shows the effect of offering the earnings subsidy only to welfare 
recipients who work a minimum number of hours, a suggestion that has been made by some welfare policy analysts. For the same reasons as work requirements in general, this will result in an increase in labor supply relative to a earnings subsidy program without any such minimum hours rule, as shown by the arrows in the figure. However, some individuals who would have increased their labor supply by a smaller number of hours will fail to do so under this program, so some labor supply gains will be lost. Also, once again, the distribution of government support shifts in this case, in relative terms, away from the worst off and toward the better off, in return for the more favorable labor supply effects.

In-Kind Transfers. There is a small literature on the effects of in-kind transfers on labor supply relative to the effects of cash transfers (Gavhari, 1994; Leonesio, 1988; Murray, 1980). At first glance, there does not seem to be any issue, given that in-kind transfers in developed countries like the U.S. do not subsidize the market price of the commodity directly, as in developing countries, but rather simply provide families with a fixed amount of the good. That fixed amount initially seems close to having the same effect as an increase in income. For example, suppose the utility function is $U(L, S, C)$ where $L$ is hours of leisure, $S$ is the quantity of the subsidized good, and $\mathrm{C}$ is the quantity of other consumption goods. Let the amount of the gift of the subsidized good be $\mathrm{pS}^{*}=\mathrm{pG}-\mathrm{t}(\mathrm{WH}+\mathrm{N})$, where $\mathrm{p}$ is the market price of $\mathrm{S}, \mathrm{G}$ is the maximum amount of the good given, $\mathrm{t}$ is the MTR in the program, and $\mathrm{W}, \mathrm{H}$, and $\mathrm{N}$ are as defined in the static labor supply model $(\mathrm{H}+\mathrm{L}=\mathrm{T})$. Then the resulting budget constraint is

$$
\mathrm{W}(1-\mathrm{t}) \mathrm{H}+\mathrm{N}(1-\mathrm{t})+\mathrm{pG}=\mathrm{pS}+\mathrm{qC}
$$


where $\mathrm{q}$ is the price of $\mathrm{C}$. This constraint looks very much like the constraint for a cash transfer, for the relative prices of $\mathrm{S}, \mathrm{C}$, and $\mathrm{H}$ (or L) are the same as they are in a cash transfer.

However, as the above-cited studies demonstrate, the more interesting case is when the optimal S resulting from the maximum problem presented by the budget constraint in (5) is less than the $S^{*}$ amount granted by the government. In this case the individual is constrained to consume more of the good than he would have if the transfer had been provided in the form of a lump sum cash grant. This distortion of the consumption of S has effects on the consumption of $\mathrm{L}$ and $\mathrm{C}$. The basic result from the studies is that if $\mathrm{S}$ and $\mathrm{L}$ are Hicks-Allen substitutes, then the effects of such an "over-provided" in-kind transfer is to increase hours of work rather than decrease them, because $\mathrm{L}$ is reduced by the excess consumption of $\mathrm{S}$. If $\mathrm{S}$ and $\mathrm{L}$ are complements however, the opposite is likely to occur.

There is no strong empirical evidence on this issue to date. The Food Stamp program in the U.S. is generally considered to be nearly equivalent to cash because the amounts of food coupons provided to families are generally less than they appear to spend, i.e., they are inframarginal (Currie, forthcoming). On the other hand, Medicaid and housing subsidies have cash-equivalent values less than one because individuals would in almost all cases consume less than the quantities provided by the government if the transfer were in cash. But what evidence there is suggests that these programs have work disincentives, but there has been no strong comparison of those effects relative to those of cash transfers. 


\section{Empirical Evidence: A Short Review}

Introduction. The volume of research on the effects of welfare programs on labor supply has been cyclical over the last three decades. While there was a large amount of research in the late 1960s and 1970s, there was relatively little in the 1980s and early 1990s. There has been a resurgence of interest in these issues in the 1990s, however, accompanied by an increase in the volume of new work.

Methodological controversies have been a major focus in this literature and continue to be at the present time. One controversy has been over the relative merits of structural versus reduced-form estimation of the effects of policy variation, and another has been over the best sources of policy variation to use when estimating either structural or reduced form models. This distinction is not always fully understood. The first issue concerns whether some particular source of policy variation--such as cross-state variation in welfare rules, for example-should be used to estimate black-box impacts of policy difference without using economic models in any formal sense and without estimating any underlying behavioral elasticities, such as income and substitution effects. The primary argument for structural estimation in this sense has always been that it affords a superior method of conducting out-of-sample forecasting of untested and unimplemented policies than can the estimates from reduced form models. ${ }^{20}$ While the evidence on this issue is not conclusive at this time, it is a fact that estimation of reduced-form impacts of policy variation has become more common than structural estimation in the literature.

The second issue concerns whether the best source of variation to use is pure cross-

20 See Heckman (2000) for a discussion. 
sectional variation in policies across areas (when it is available), variation across areas in how policies change over time (e.g., the state fixed effects model), or variation between somehowdefined "eligible" and "ineligible" populations, either in pure cross section or over time (the difference-in-difference method). The latter two sources of variation have been more heavily used than the first. When these different sources of variation are each used to estimate justidentified models, it is generally not possible to test them against one another, which is one reason for the continued disagreement on which source is preferable. But whatever source of variation is used, either structural or reduced form estimation can be applied to it. ${ }^{21}$

The issue of the source of policy variation is the more important one in the analysis of the effect of welfare programs on labor supply. Some programs in the U.S. (TANF, Medicaid, child care subsidies, housing programs) have considerable cross-sectional variation as well as variation over time that differs across areas, furnishing the opportunity for the use of more than one type for identification. Yet other programs (the EITC, Food Stamps, SSI) have essentially no crosssectional variation because they are national in scope and the same rules apply to everyone. These latter programs must use some other source of variation for estimation and usually it is a source which will rest on more tenuous assumptions.

The review of the empirical literature below is divided into sections based partly on these issues. ${ }^{22}$ The pre-1995 literature will first be reviewed, for that literature tended to estimate

${ }^{21}$ Using non-policy sources of variation to identify policy impacts is in a different class. The main argument for using such non-policy variation (e.g., variation in wages alone to identify the effects of $\mathrm{W}(1-\mathrm{t})$ when there is no variation in $\mathrm{t}$ ) is that it is the only alternative if there is no direct policy variation cross-sectionally or over time.

${ }^{22}$ For reasons of length, and not because of any lack of inherent interest, the literature from countries other than the U.S. will not be reviewed. 
structural models and use certain types of sources of variation for identification. The post-1995 literature will then be reviewed, first covering structural estimation and then estimation of reduced-form policy impacts. For the most part, the labor supply literature in this area is much thinner than might be supposed and hence there are not many studies to review.

$\underline{\text { Pre-1995 Estimates. }}$ There have been several major reviews of the pre-1995 literature on the effects of welfare programs on labor supply (Danziger et al., 1981; Moffitt, 1992; Hoynes, 1997) which exhaustively cover the studies. That literature will therefore not be rereviewed here in detail but rather merely summarized. Most of the studies estimated the effects of the AFDC program and consisted of structural or quasi-structural models, using pure cross-state variation in AFDC benefits along with other sources of identification to obtain parameter estimates. ${ }^{23}$ They found almost universally that the AFDC program reduced labor supply by from 10 to 50 percent of non-AFDC levels. The substitution and income elasticities estimated from the literature fell into the general range of those elasticities obtained from the literature on substitution and income effects estimated from wage and nonlabor income variation, respectively, suggesting that the simple static theory--which presumes these elasticities to be the same--is roughly verified.

This literature also addressed the effects of a reduction in $\mathrm{t}$ and the ambiguity of labor supply response noted in the previous section. In general, it was found that for single mothers, the primary eligibility group for benefits, average labor supply was quite inelastic with respect to changes in tholding $\mathrm{G}$ fixed, suggesting that the labor-supply-inducing and labor-supplydecreasing effects roughly cancelled each other out (see Moffitt, 1992, for a discussion). While these effects were obtained by simulation, using structural estimates of substitution and income

23 There was one state fixed effects estimate from this literature (Moffitt, 1986). 
elasticities to forecast the positive and negative labor supply responses to a reduction in t over the income and hours distribution, they are consistent with reduced form estimates from the negative income tax experiments. ${ }^{24}$ The NIT experiments tested multiple $\mathrm{G}$ and $\mathrm{t}$ combinations and hence it was possible to determine the average effect of a change in $\mathrm{t}$, holding $\mathrm{G}$ fixed, by comparing treatment-control outcomes across different experimental groups. The results showed a very mixed pattern of results, with labor supply levels sometimes higher and sometimes lower with no consistent pattern and with few significant differences (SRI International, 1983, Table 3.9).

Fortin et al. (1993) addressed the social welfare issue referred to previously by simulating the effects of different combinations of $\mathrm{G}$ and $\mathrm{t}$ on a variety of social welfare indices, most of them based on Atkinson-style inequality aversion scales. Using a calibrated model with assumed elasticities, and a data set of Canadian families, the results showed a large number of "perverse" effects of a reduction in t on labor supply, consistent with prior evidence. However, the programs that most often maximized social welfare were those with relatively low levels of both $\mathrm{G}$ and $\mathrm{t}$. At these levels, the amount of redistribution is not very high and, further, they occur in a range where reductions in $t$ tend to increase average labor supply. The paper thus presents a useful exercise on how to address this important question, even though the results may be specific to the data set used and to the income distribution in the Canadian data set used for the analysis.

A scattering of estimates were obtained for other programs. Estimates of the effect of the

${ }^{24}$ The results of the NIT experiments will also not be reviewed here. See Moffitt and Kehrer (1981) and Burtless (1987) for reviews. 
Food Stamp program showed very little labor supply response, possibly because the benefit amounts in the program are quite small relative to those of cash programs. There were a fairly large number of estimates of the effect of Medicaid on labor supply, with the majority indicating some significant work disincentives of the program, albeit concentrated among those in poor health (see Gruber, forthcoming, for a review of these studies). One study attempted to estimate the labor supply effects of housing programs using a very indirect method of identification, rather than variation in housing programs per se, and found the program to reduce hours of work by about 4 percent (Murray, 1980). There were also a number of structural estimates of the effect of the price of child care on labor supply, both before and after 1995 and using similar methologies. These studies almost uniformly show negative price effects on employment, implying that child care subsidies will indeed increase employment (see Blau, forthcoming, for a review of this literature).

Post-1995 Structural Estimates. Because of the decline in structural estimation in the labor supply literature, there have been few structural estimates of labor supply responsiveness. Table 4 shows four of the more well-known studies. Hoynes (1996) studied the AFDC-UP program and found it to have significant negative effects on the labor supply of husbands and wives, but that marginal reductions in $\mathrm{t}$ had little effect, consistent with prior work. Hagstrom (1996) estimated the effect of the Food Stamp program on labor supply and found it to have very small effects, even smaller than those found in the pre-1995 literature. This reinforces the sense that the Food Stamp program has little effect on work disincentives. Keane and Moffitt (1998) focused on the labor supply effects of participating in multiple programs, including not only AFDC but also Food Stamps, subsidized housing, and the Medicaid program. They showed that 
cumulative tax rates were generally greater than 100 percent in this case. Nevertheless, while their estimated substitution and income elasticities were sizable, the net effect on labor supply of reducing the marginal tax rates to a level below 100 percent was negligible. Meyer and Rosenbaum (2001) focused on an attempt to explain the increase in employment rates among single mothers from 1984-1996. They found that AFDC benefits and tax rates (the latter affecting potential benefits if working) had expected effects on employment probabilities, but that the time series increase in single mother employment was less affected by changes in those parameters and other welfare variables than a change in the generosity of the EITC over the period. ${ }^{25}$

Some of the simulations of alternative programs conducted by Keane and Moffitt bore on one of the issues raised in the theoretical section above, which is whether wage and earnings subsidies are likely to draw welfare recipients off welfare and into the (subsidized) private labor market. Keane and Moffitt found AFDC and Food Stamps to have heavy stigma attached to them but they assumed that there would be no stigma associated with a wage or earnings subsidy program. As a consequence, they found the latter types of programs to have much higher forecasts of work incentives than reductions in the welfare tax rate $t$. Whether there would be any stigma attached to such programs is not clear, however (see also Keane (1995)).

Post-1995 Reduced Form Policy Impact Estimates. The literature on estimating the reduced form impact of policy changes on employment and earnings is also exceeding modest.

25 Because Meyer and Rosenbaum examined employment rather than hours of work, the "perverse" effect of a change in t could not occur. They briefly examined effects on hours of work as a sensitivity test but they noted that the model independent variables were not set up for that dependent variable. 
Yelowitz (1995) used the expansion of Medicaid in different states and in different age groups of children to estimate their impact on employment, and found those expansions to have a positive effect on employment rates. A number of policy-impact studies of the effect of the EITC on labor supply have also been conducted (e.g., Eissa and Liebman, 1996; Eissa and Hoynes, 1998). The results show that the EITC increases employment probabilities for single mothers but has no net effect on their hours of work, if working. This is consistent with the notion that labor supply is encouraged among initial nonworkers but that the taxback region of the program reduces labor supply enough to cancel out the effects among workers. As noted above, Meyer and Rosenbaum (2001) also estimated the effects of the EITC on single mothers and also found it to have significantly positive effects on employment probabilities. The results from the Eissa-Hoynes study shed light on the effects of the EITC on married men and married women. The findings were that the EITC increased the employment probabilities of married men but decreased those of married women, and that it decreased the hours of work of workers of both men and women. The results for married women may be because many of them are located in the taxback region because their husbands have significant earnings in and of themselves and the wives may be regarded as the marginal worker, even at the first dollar. The hours results for men may be a result of the same taxback region. ${ }^{26}$

These constitute the main body of this type of work and is, as already noted, quite small in volume. There have been no studies of this type for the SSI program at all, nor any new

${ }^{26}$ See Hotz and Scholz (forthcoming) for a more detailed review of these EITC studies and a number of others that used indirect estimation methods to simulate the effect of the EITC on labor supply. It should be noted that the Eissa-Hoynes study, while using direct policy variation for reduced form estimation, also translated their impacts into estimated income and substitution elasticities. 
studies of the Food Stamp or housing programs.

Many more studies have been conducted of the effects of the 1996 welfare legislation, the Personal Responsibility and Work Opportunity Reconciliation Act (PRWORA), which transformed the AFDC program into the Temporary Assistance for Needy Families (TANF) program by introducing time limits, work requirements, and devolved responsibility and block grant funding to the states (see Moffitt, 2001a, for a detailed review of its provisions). There were also a number of studies of so-called "waiver" programs just prior to 1996 under which states undertook to test programs that were in most cases similar to the later national PRWORA legislation. Evaluating these waiver programs was made possible by the fact that different states tested different types of programs and did so at different calendar times, furnishing variation in policy which could be used to estimate impacts on labor supply and other outcomes. However, evaluating the 1996 legislation is difficult because it was implemented nationally and all states had to come into compliance with its main provisions. Thus there was no cross-state variation in the overall nature of the program.

As a consequence, difference-in-difference methods have generally been used for the evaluation of the effects of TANF. As Ellwood (2000) and Schoeni and Blank (2000) note, use of these methods is particularly problematic when other reforms, such as the EITC, were occurring roughly simultaneously, and when business cycle and economy-wide trends were occurring which could affect different groups differently. A further difficulty in evaluation has arisen because the separate impacts of time limits, work requirements, and other provisions has been difficult to determine even in the pre-1996 waiver period. This is partly because a state's choice of those components is correlated with other characteristics of the state, and partly 
because their implementation was often significantly different than what would be expected from their formal definition. As a consequence, while there are a number of estimates of the overall impact of welfare reform in this period, taken as a whole, there are almost no credible studies of the impact of different individual components of reform taken individually. ${ }^{27}$

Table 5 shows the main studies estimating the overall impact of the pre-1996 waiver programs and of TANF. With a few exceptions, the studies show waivers to have had positive effects on most measures of labor supply and negative effects on measures of AFDC participation, as expected. These studies all control for the state of the economy, usually by controlling for the unemployment rate, so the estimated effects of welfare reform are all intended to be net of the strong economy.

Two entries in Table 5 are for experiments which made use of traditional randomassignment methods rather than cross-state variation in the presence of reform. These studies generally also find positive effects on employment and earnings and negative effects on welfare participation. ${ }^{28}$ However, random-assignment methods are not well-suited for major structural reforms like the pre-1996 welfare waivers--or for TANF itself--because such structural reforms tend to cause changes in local labor markets and local communities that feed back onto the control group, and because structural reforms tend to have significant effects on entry into

27 An exception is Grogger $(2000,2001)$, who has attempted to estimate the independent effects of time limits by using age variation in children combined with assumptions that that variation does not interact identically with other welfare reform features. The validity of the assumptions needed for these methods to be unbiased is unknown.

${ }^{28}$ There have been many more random-assignment studies in this period but those listed in Table 5 constitute those which had all of the main features of PRWORA, namely, time limits, work requirements, sanctions, and enhanced earnings disregards, and which made these reforms within the AFDC system rather than outside of it. 
welfare. Experiments produce biased estimates of total reform effects under these circumstances. $^{29}$

The estimates of the effects of TANF are generally positive on employment and earnings but not always. Further, in some cases the effects of TANF cannot be separated from the effects of other policy changes occurring at the same time, as emphasized by Ellwood (2000); he concludes that these difficulties are sufficiently severe that the separate contributions of welfare reform, the EITC, and the economy cannot be identified. McKernan et al. (2000) and Schoeni and Blank (2000) are the other two studies using difference-in-difference methods, one of which finds TANF to have increased employment while the other finds it not to have done so but to have affected family earnings, income, and AFDC participation. The two studies used different control groups so this may be the source of the difference. What evidence there is, therefore, indicates some TANF effects in the expected direction but the small number of studies and problems in statistical inference make the conclusions rather uncertain.

\section{Summary}

The labor supply and other work incentive effects of welfare programs have long been a central concern in economic research. Work has also been an increasing focus of policy reforms in the U.S., culminating with a number of major policy changes in the 1990s whose intent was to increase employment and earnings levels of welfare recipients and other

29 Another difficulty in the use of experiments for evaluating structural welfare reform is that the control group is often contaminated by the general atmosphere of reform which changes the expectations of the eligible population as a whole. 
disadvantaged individuals. This review of the theoretical and empirical literature on this issue reveals that there is much that remains to be done to gain a full understanding of these programs. Many issues relating to the optimal levels of welfare program parameters and the social desirability of labor supply effects in different parts of the income distribution remain to be studied, a key issue. New policy initiatives in the area of work requirements, time limits, and other topics have been understudied, as have dynamic models of labor supply response. The proper integration of the complex multi-program environment in the U.S. is also a needed area of research.

Even more on the empirical side, more research is needed in a number of areas. While traditional studies of the effect of AFDC guarantee and tax rates are reasonably plentiful, structural or quasi-structural models of the effects of welfare reforms in the 1990s are rare and yet are needed to understand the mechanisms by which effects of that reform have taken place as well as to forecast the effects of new policies. Many programs other than TANF are quite understudied, especially the SSI program but also including the Food Stamp and Medicaid programs. Even the EITC, which has seen a considerable amount of research attention, has at present been the subject of only a modest number of studies. Thus there are many areas of new research to be conducted on the effects of welfare programs on labor supply. 


\section{References}

Akerlof, G. 1978. "The Economics of 'Tagging' as Applied to the Optimal Income Tax, Welfare Programs, and Manpower Planning." American Economic Review 68 (March): 8-19.

Ashenfelter, O. 1983. "Determining Participation in Income-Tested Social Programs." Journal of the American Statistical Association 78 (September): 517-525.

Barth, M. and D. Greenberg. 1971. "Incentive Effects of Some Pure and Mixed Transfer Systems." Journal of Human Resources 6 (Spring): 149-170.

Beaudry, P. and C. Blackorby. 1998. "Taxes and Employment Subsidies in Optimal Redistribution Programs." Working Paper 6355. Cambridge: National Bureau of Economic Research.

Besley, T. and S. Coate. 1992a. "Understanding Welfare Stigma: Taxpayer Resentment and Statistical Discrimination.” Journal of Public Economics 48 (July): 165-163.

. 1992b. "Workfare Versus Welfare: Incentive Arguments for Work

Requirements in Poverty-Alleviation Programs." American Economic Review 82 (March): 249261.

Besley, T. and S. Coate. 1995. "The Design of Income Maintenance Programmes." Review of Economic Studies 62: 187-221.

Blau, D. Forthcoming. "Child Care Subsidy Programs." In Means-Tested Transfer Programs in the U.S., ed. R. Moffitt. Chicago: University of Chicago Press.

Bloom, D. and C. Michalopoulos. 2001. "How Welfare and Work Policies Affect Employment and Income: A Synthesis of Research." New York: Manpower Demonstration Research Corporation.

Blundell, R. and T. MaCurdy. 1999. "Labor Supply: A Review of Alternative Approaches." In Handbook of Labor Economics, Vol. 3A, eds. O. Ashenfelter and D. Card. Elsevier-NorthHolland.

Browning, E. 1975. Redistribution and the Welfare System. Washington: American Enterprise Institute.

Burke, V. 2001. Cash and Non-Cash Benefits for Persons with Limited Income: Eligibility Rules, Recipient and Expenditure Data, FY1998-FY2000.. Washington: Congressional Research 
Service.

Burtless, G. "The Work Response to a Guaranteed Income: A Survey of the Experimental Evidence" In Lessons from the Income Maintenance Experiments, ed A. Munnell. Boston: Federal Reserve Bank and Brookings, 1987.

Chone, Ph. and G. Laroque. 2001. "Optimal Incentives for Labor Force Participation.” INSEE Working Paper 2001-25.

Coe, N.; G. Acs; R. Lerman; and K. Watson. 1998. "Does Work Pay? A Summary of the Work Incentives Under TANF." Washington: Urban Institute.

Cuff, K. 2000. "Optimality of Workfare with Heterogeneous Preferences." Canadian Journal of Economics 33 (February): 149-174.

Currie, J. Forthcoming. "Food and Nutrition Programs." In Means-Tested Transfers in the U.S., ed. R. Moffitt. Chicago: University of Chicago Press.

Danziger, S.; R. Haveman; and R. Plotnick. "How Income Transfers Affect Work, Savings, and the Income Distribution: A Critical Review " Journal of Economic Literature 19 (September 1981): 975-1028.

Eissa, N. and H. Hoynes. 1998. "The Earned Income Tax Credit and the Labor Supply of Married Couples.” Working Paper 6856. Cambridge: National Bureau of Economic Research.

Eissa, N. and J. Liebman. 1996. "Labor Supply Response to the Earned Income Tax Credit." Quarterly Journal of Economics 111 (May): 605-637.

Ellwood, D. 2000. "The Impact of the Earned Income Tax Credit and Social Policy Reforms on Work, Marriage, and Living Arrangements." National Tax Journal 53, Pt 2 (December): 10631105.

Fein, D.; D. Long; J. Behrens; and W. Lee. 2001. "The ABC Evaluation: Turning the Corner: Delaware's A Better Chance Welfare Reform Program at Four Years." Cambridge: Abt Associates.

Fortin, B., M. Truchon; and L. Beausejour. 1993. "On Reforming the Welfare System: Workfare Meets the Negative Income Tax." Journal of Public Economics 51 (1993): 119-151.

Friedman, M. Capitalism and Freedom. 1962. Chicago: University of Chicago Press.

Garfinkel, I. 1973. "A Skeptical Note on 'The Optimality' of Wage Subsidy Programs.” American Economic Review 63 (June): 447-453. 
Gavhari, F. 1994. "In-Kind Transfers, Cash Grants and Labor Supply." Journal of Public Economics 55 (November): 495-504.

Gottschalk, P. 1988. “The Impact of Taxes and Transfers on Job Search.” Journal of Labor Economics 6 (July): 362-375.

Grogger, J. 2000. “Time Limits and Welfare Use.” Working Paper 7709. Cambridge: National Bureau of Economic Research.

. 2001. "The Effects of Time Limits and Other Policy Changes on Welfare Use, Work, and Income Among Female-Headed Families." Working Paper 8153. Cambridge: National Bureau of Economic Research.

Gruber, J. Forthcoming. "Medicaid." In Means-Tested Transfer Programs in the U.S., ed. R. Moffitt. Chicago: University of Chicago Press.

Hagstrom, P. 1996. "The Food Stamp Participation and Labor Supply of Married Couples: An Empirical Analysis of Joint Decisions." Journal of Human Resources 31 (Spring): 331-358.

Heckman, J. 2000. "Causal Parameters and Policy Analysis in Economics: A Twentieth Century Retrospective." Quarterly Journal of Economics 115 (February): 45-97

Hotz, V.J. and K. Scholz. Forthcoming. "The Earned Income Tax Credit." In Means-Tested Transfers in the U.S, ed. R. Moffitt. Chicago: University of Chicago Press.

Hoynes, H. 1996. "Welfare Transfers in Two-Parent Families: Labor Supply and Welfare Participation under AFDC-UP." Econometrica 64 (March): 295-332.

. 1997. Hoynes, H.. "Work, Welfare, and Family Structure: What Have We Learned?"

In Fiscal Policy: Lessons from Economic Research, ed. A. Auerbach. Camb: MIT Press.

Hubbard, G.; J. Skinner; and S. Zeldes. 1995. "Precautionary Saving and Social Insurance." Journal of Political Economy 103 (April): 360-399.

Immonen, R; R. Kanbur; M. Keen; and M. Tuomala. 1998. "Tagging and Taxing: The Optimal Use of Categorical and Income Information in Designing Tax/Transfer Schemes." Economica 65 (May): 179-192.

Keane, M.. 1995. “A New Idea for Welfare Reform.” Federal Reserve Bank of Minneapolis Quarterly Review 19 (Spring): 2-28.

Keane, M. and R. Moffitt. 1998. "A Structural Model of Multiple Welfare Program Participation and Labor Supply." International Economic Review 39 (August): 553-589. 
Kesselman, J.R. 1969. "Labor-Supply Efffects of Income, Income-Work, and Wage Subsidies." Journal of Human Resources 4 (Summer): 275-292.

. 1973. "Incentive Effects of Transfer Systems Once Again." Journal of Human Resources 8 (Winter): 119-129.

. 1976. “Tax Effects on Job Search, Training, and Work Effort.” Journal of Public Economics 6 (October): 255-272.

Leonesio, M. 1988. "In-Kind Transfers and Work Incentives.” Journal of Labor Economics 4 (October): 515-529.

Levy, F. 1979. "The Labor Supply Effects of Female Heads, or AFDC Work Incentives Don't Work Too Well." Journal of Human Resources 14 (Winter): 76-97

Lindbeck, A.;S. Nyberg; and J. Weibull. 1999. "Social Norms, the Welfare State, and Voting." Quarterly Journal of Economics 114 (February): 1-35.

Lurie, I., ed. 1975. Integrating Income Maintenance Programs. NY: Academic Press.

McKernan, S.-M.; R. Lerman; N. Pindus; and J. Valente. 2000. "The Relationship Between Metropolitan and Non-Metropolitan Locations, Changing Welfare Policies, and the Employment of Single Mothers." Mimeo, Urban Institute.

Meyer, B. and D.Rosenbaum. 2001. "Welfare, the Earned Income Tax Credit, and the Labor Supply of Single Mothers.” Quarterly Journal of Economics 116 (August): 1063-1114.

Miller, R. and S. Sanders. 1997. "Human Capital Development and Welfare Participation." Carnegie-Rochester Conference Series on Public Policy 46 (June): 1-43.

Moffitt, R. 1983. "An Economic Model of Welfare Stigma." American Economic Review 73 (December): 1023-1035.

. 1985. "Unemployment Insurance and the Distribution of Unemployment Spells." Journal of Econometrics 28: 85-101.

. 1986. "Work Incentives in Transfer Programs (Revisited): A Study of the AFDC Program." In Research in Labor Economics, Vol. 8, ed. R. Ehrenberg. JAI Press.

1992. "Incentive Effects of the U.S. Welfare System: A Review." Journal of Economic Literature 30 (March): 1-61.

. 1999. "The Effect of Pre-PRWORA Waivers on AFDC Caseloads and Female 
Earnings, Income, and Labor Force Behavior." In Economic Conditions and Welfare

Reform,ed.S. Danziger. Kalamazoo: Upjohn Institute.

. 2001a. "The Temporary Assistance for Needy Families Program." In Means-Tested Transfer Programs in the U.S., ed. R. Moffitt. Chicago: University of Chicago Press, forthcoming.

. 2001b. "Economic Effects of Means-Tested Transfers in the U.S." Tax Policy and the Economy, forthcoming.

Moffitt, R. and K. Kehrer. "The Effect of Tax and Transfer Programs on Labor Supply: The Evidence from the Income Maintenance Experiments." In Research in Labor Economics, Vol. IV, ed. R. Ehrenberg. Greenwich, Conn: JAI Press, 1981.

Mueser, P.; J. Hotchkiss; C. King; P. Rokicki; and D. Stevens. 2000. “The Welfare Caseload, Economic Growth and Welfare-to-Work Policies: An Analysis of Five Urban Areas." Mimeo, University of Missouri.

Murray, M. 1980. "A Reinterpretation of the Traditional Income-Leisure Model, with Application to In-Kind Subsidy Programs." Journal of Public Economics 14 (August): 69-81.

Nechyba, T. 1999. "Social Approval, Values, and AFDC: A Re-Examination of the Illegitimacy Debate.” Working Paper 7240. Cambridge: National Bureau of Economic Research.

O’Neill, J. and M. A. Hill. 2001. "Gaining Ground? Measuring the Impact of Welfare Reform on Welfare and Work." NY: Manhattan Institute.

Parsons, D. 1996. "Imperfect 'Tagging' in Social Insurance Programs." 吕urnal of Public Economics 62 (October): 183-208.

Rowe, G. and T. Roberts. 2002. "Welfare Rules Databook Tables: State Policies as of July 2000.” Washington: Urban Institute.

Schoeni, R. and R. Blank. 2000. "What Has Welfare Reform Accomplished? Impacts on Welfare Participation, Employment, Income, Poverty, and Family Structure." Working Paper 7627.

Cambridge: National Bureau of Economic Research.

Smeeding, T. 1982. "Alternative Methods for Valuing Selected In-Kind Transfer Benefits and Measuring Their Effects on Poverty." Technical Paper 50. Washington: Bureau of the Census.

SRI International, Inc. 1983. "Final Report of the Seattle/Denver Income Maintenance Experiment: Volume I." Menlo Park, California. 
Tobin, J. 1965. "On Improving the Status of the Negro." Daedalus 94 (Fall): 878-99.

U.S. House of Representatives. 2000. Background Material and Data on Programs Within the Jurisdiction of the Committee on Ways and Means. Washington: Government Printing Office.

Yelowitz, A. 1995. "The Medicaid Notch, Labor Supply, and Welfare Participation: Evidence from Eligibility Expansions." Quarterly Journal of Economics 105 (1995): 909-940.

Zeckhauser, R. 1971. "Optimal Mechanisms for Income Transfer." American Economic Review 61 (June): 324-334. 
Table 1

Characteristics of Major Means-Tested Transfer Programs in the U.S.

\begin{tabular}{|c|c|c|c|c|c|}
\hline Program & $\begin{array}{l}\text { Main Eligible } \\
\text { Population }^{\mathrm{a}}\end{array}$ & $\begin{array}{l}\text { Form of } \\
\text { Assistance }\end{array}$ & $\begin{array}{c}\text { Annual } \\
\text { Expenditures }^{\mathrm{b}} \\
(\mathrm{FY} 2000)\end{array}$ & $\begin{array}{l}\text { Average Monthly } \\
\text { Expenditure for } \\
\text { Family of } 3 \\
\text { (FY2000) }\end{array}$ & $\begin{array}{l}\text { Marginal Tax Rate } \\
\text { on Earnings }\end{array}$ \\
\hline $\begin{array}{l}\text { Temporary } \\
\text { Assistance for } \\
\text { Needy Families }\end{array}$ & $\begin{array}{l}\text { Mostly single } \\
\text { mother families }\end{array}$ & Cash & 14,490 & 600 & $\begin{array}{l}\text { Ranges across } \\
\text { states from } 0 \text { to } 100 \\
\text { percent }\end{array}$ \\
\hline $\begin{array}{l}\text { Supplemental } \\
\text { Security Income }\end{array}$ & $\begin{array}{l}\text { Aged, blind, and } \\
\text { disabled } \\
\text { individuals and } \\
\text { families }\end{array}$ & Cash & 35,066 & 1326 & $50 \%$ \\
\hline $\begin{array}{l}\text { Earned Income Tax } \\
\text { Credit }\end{array}$ & $\begin{array}{l}\text { Individuals with } \\
\text { positive earnings }\end{array}$ & Cash & $30,000^{c}$ & $135^{\mathrm{e}}$ & $\begin{array}{l}\text { Ranges from }-40 \% \\
\text { to } 21 \%\end{array}$ \\
\hline Food Stamps & $\begin{array}{l}\text { All individuals and } \\
\text { families }\end{array}$ & Food coupons & 20,341 & 279 & $30 \%$ \\
\hline Medicaid & $\begin{array}{l}\text { Families with } \\
\text { dependent children, } \\
\text { disabled, elderly }\end{array}$ & $\begin{array}{l}\text { Health care } \\
\text { services }\end{array}$ & 207,195 & $2,238^{f}$ & $0 \%$ or $>100 \%$ \\
\hline
\end{tabular}


Table 1 (continued)

\begin{tabular}{|c|c|c|c|c|c|}
\hline Program & $\begin{array}{l}\text { Main Eligible } \\
\text { Population }^{\mathrm{a}}\end{array}$ & $\begin{array}{l}\text { Form of } \\
\text { Assistance }\end{array}$ & $\begin{array}{c}\text { Annual } \\
\text { Expenditures }^{\text {b }} \\
(\text { FY2000) }\end{array}$ & $\begin{array}{l}\text { Average Monthly } \\
\text { Expenditure for } \\
\text { Family of } 3 \\
\text { (FY2000) }\end{array}$ & $\begin{array}{l}\text { Marginal Tax Rate } \\
\text { on Earnings }\end{array}$ \\
\hline $\begin{array}{l}\text { Subsidized } \\
\text { Housing }^{\mathrm{d}}\end{array}$ & $\begin{array}{l}\text { All individuals and } \\
\text { families }\end{array}$ & Housing units & 22,498 & $422^{g}$ & $\begin{array}{l}\text { Ranges from } 20 \% \\
\text { to } 30 \%\end{array}$ \\
\hline \multicolumn{6}{|l|}{ Child Care } \\
\hline $\begin{array}{l}\text { Child Care } \\
\text { Block Grant }\end{array}$ & $\begin{array}{l}\text { Working parents of } \\
\text { children under } 13\end{array}$ & $\begin{array}{l}\text { Child care } \\
\text { assistance }\end{array}$ & 6,934 & $861^{\mathrm{f}}$ & $\begin{array}{l}\text { Sliding fee scale set } \\
\text { by states (can be } \\
\text { zero) }\end{array}$ \\
\hline $\begin{array}{l}\text { Dependent Care } \\
\text { Tax Credit }\end{array}$ & $\begin{array}{l}\text { Working parents of } \\
\text { children under } 13\end{array}$ & $\begin{array}{l}\text { Nonrefundable } \\
\text { credit in federal } \\
\text { income tax }\end{array}$ & 2,200 & $75^{\mathrm{h}}$ & $\begin{array}{l}\text { Credit is } 20 \% \text { to } \\
30 \% \text { of eligible } \\
\text { expenses }\end{array}$ \\
\hline
\end{tabular}

\section{Notes:}

a In addition to low income and assets

b Combined federal and state and local; in millions

${ }^{\mathrm{c}}$ Includes tax reduction as well as refundable portion

${ }^{\mathrm{d}}$ Combined Section 8 and public housing

${ }^{\mathrm{e}}$ Per filing unit, tax year 2000

${ }^{f}$ FY1999

g Family or dwelling unit

${ }^{\mathrm{h}}$ FY1998, for 2 children in child care

Sources: Blau (forthcoming), Burke (2001), Rowe and Roberts (2002), U.S. House of Representatives (2000) 
Table 2

Multiple Benefit Receipt by Nonelderly Single Mother Households, 1997 (percent distribution)

\begin{tabular}{lc}
\hline & \\
\hline & \\
No Program & 48.0 \\
AFDC, Food Stamps, Medicaid, and another program & 10.4 \\
AFDC, Food Stamps, and Medicaid only & 6.0 \\
AFDC, Medicaid, and another program & 1.1 \\
AFDC and Medicaid only & 0.7 \\
Medicaid only & 6.2 \\
Food Stamps only & 1.8 \\
Other cash transfers only & 4.9 \\
Other & 18.0 \\
Total & 100.0 \\
\hline
\end{tabular}

Notes:

Source: Tabulations from the Survey of Income and Program Participation by Kara Levine, University of Wisconsin. 
Table 3

Cumulative Marginal Tax Rates for Recipients of

TANF and Food Stamps in 12 States, 1997

(percent)

From No Work to From Part Time Work From Minimum Wage

Part Time Work at to Full Time Work to \$9 Hourly Wage at

Minimum Wage Minimum Wage $\quad$ Full Time Work

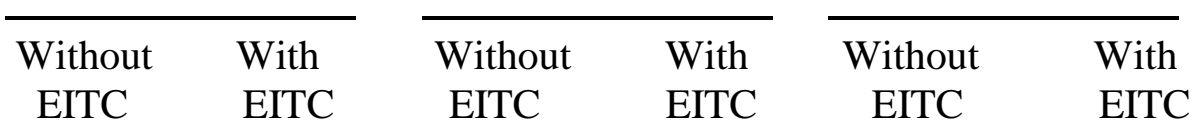

$\begin{array}{lllllll}\text { Alabama } & 46 & 6 & 33 & 9 & 24 & 58 \\ \text { California } & 50 & 9 & 67 & 33 & 67 & 89 \\ \text { Colorado } & 57 & 17 & 71 & 39 & 29 & 59 \\ \text { Florida } & 46 & 6 & 59 & 28 & 35 & 63 \\ \text { Massachusetts } & 57 & 13 & 64 & 28 & 64 & 87 \\ \text { Michigan } & 63 & 23 & 84 & 47 & 35 & 63 \\ \text { Minnesota } & 55 & 8 & 65 & 27 & 69 & 89 \\ \text { Mississippi } & 34 & -6 & 32 & 7 & 24 & 55 \\ \text { New Jersey } & 64 & 23 & 62 & 30 & 41 & 67 \\ \text { New York } & 65 & 16 & 67 & 27 & 55 & 84 \\ \text { Texas } & 50 & 10 & 24 & 0 & 25 & 57 \\ \text { Washington } & 71 & 30 & 67 & 33 & 50 & 76\end{array}$

Notes:

Income includes earnings, TANF and Food Stamp benefits, federal and state EITC amounts, less employee payroll and federal and state income taxes. Minimum Wage is \$5.15 per hour. Family size of three assumed.

Source: Coe et al. (1998, Tables 4,5). 
Table 4

Recent Structural Models of the Effect of Welfare Programs on Labor Supply

\begin{tabular}{|c|c|c|c|c|c|}
\hline $\begin{array}{l}\text { Author and } \\
\text { Program }\end{array}$ & Data & Population & $\begin{array}{c}\text { Dependent } \\
\text { Variable }\end{array}$ & $\begin{array}{l}\text { Welfare } \\
\text { Variables }\end{array}$ & Results \\
\hline $\begin{array}{l}\text { Hoynes (1996) } \\
\text { AFDC-UP }\end{array}$ & $\begin{array}{l}\text { Survey of Income } \\
\text { and Program } \\
\text { Participation, 1983- } \\
1986\end{array}$ & $\begin{array}{l}\text { Low Asset Married } \\
\text { Couples }\end{array}$ & $\begin{array}{l}\text { Labor Supply and } \\
\text { Participation in the } \\
\text { AFDC-UP Program }\end{array}$ & $\begin{array}{l}\text { AFDC Guarantee } \\
\text { and Tax Rate } \\
\text { evaluated at } \\
\text { specific labor } \\
\text { supply points }\end{array}$ & $\begin{array}{l}\text { AFDC-UP has } \\
\text { sizable negative } \\
\text { effect on labor } \\
\text { supply; marginal } \\
\text { changes in G and t } \\
\text { have little effect }\end{array}$ \\
\hline $\begin{array}{l}\text { Hagstrom (1996) } \\
\text { Food Stamps }\end{array}$ & $\begin{array}{l}\text { Survey of Income } \\
\text { and Program } \\
\text { Participation, } 1984\end{array}$ & $\begin{array}{l}\text { Low Asset Married } \\
\text { Couples }\end{array}$ & $\begin{array}{l}\text { Labor Supply and } \\
\text { Participation in } \\
\text { Food Stamps }\end{array}$ & $\begin{array}{l}\text { Food Stamp } \\
\text { Guarantee and Tax } \\
\text { Rate }\end{array}$ & $\begin{array}{l}\text { Weak labor supply } \\
\text { effects }\end{array}$ \\
\hline $\begin{array}{l}\text { Keane and Moffitt } \\
\text { (1998) } \\
\text { AFDC, Food } \\
\text { Stamps, and } \\
\text { housing }\end{array}$ & $\begin{array}{l}\text { Survey of Income } \\
\text { and Program } \\
\text { Participation, } 1984\end{array}$ & $\begin{array}{l}\text { Low Asset Single } \\
\text { Mothers }\end{array}$ & $\begin{array}{l}\text { Labor Supply and } \\
\text { Participation in } \\
\text { AFDC, Food } \\
\text { Stamps, and } \\
\text { Subsidized } \\
\text { Housing }\end{array}$ & $\begin{array}{l}\text { Guarantees and Tax } \\
\text { Rates in AFDC, } \\
\text { Food Stamps, and } \\
\text { Subsidized } \\
\text { Housing evaluated } \\
\text { at specific labor } \\
\text { supply points }\end{array}$ & $\begin{array}{l}\text { Sub elast is } 1.82 \\
\text { and total income } \\
\text { elast is }-.21 \text {; } \\
\text { marginal changes } \\
\text { in t have no effect } \\
\text { on labor supply }\end{array}$ \\
\hline $\begin{array}{l}\text { Meyer and } \\
\text { Rosenbaum (2001) } \\
\text { AFDC, Food } \\
\text { Stamps, and EITC }\end{array}$ & $\begin{array}{l}\text { Current Population } \\
\text { Survey, 1984-1996 }\end{array}$ & Single Mothers & $\begin{array}{l}\text { Probability of } \\
\text { Working }\end{array}$ & $\begin{array}{l}\text { AFDC and Food } \\
\text { Stamp Guarantee } \\
\text { and expected } \\
\text { benefits if work }\end{array}$ & $\begin{array}{l}\text { Guarantees reduce } \\
\text { employment } \\
\text { probability and tax } \\
\text { declines increase }\end{array}$ \\
\hline
\end{tabular}




\section{Table 5}

Studies of the Overall Effect of Welfare Reform on Labor Supply

\begin{tabular}{|c|c|c|c|c|}
\hline Study & $\begin{array}{l}\text { Program(s) } \\
\text { Studied }\end{array}$ & $\begin{array}{c}\text { Dependent } \\
\text { Variable }\end{array}$ & $\begin{array}{c}\text { Source of } \\
\text { Program Variation }\end{array}$ & $\begin{array}{l}\text { Estimated Effect } \\
\text { of Welfare Reform }\end{array}$ \\
\hline \multicolumn{5}{|l|}{ Pre-1996 Waiver Programs } \\
\hline $\begin{array}{l}\text { Bloom and Michalopoulos } \\
\text { (2001) }\end{array}$ & $\begin{array}{l}\text { Waiver programs in } \\
\text { Connecticut, Florida, } \\
\text { and Vermont }\end{array}$ & $\begin{array}{l}\text { Employment, earnings, } \\
\text { income, AFDC } \\
\text { participation }\end{array}$ & $\begin{array}{l}\text { Randomized } \\
\text { assignment on } \\
\text { population of AFDC } \\
\text { recipients }\end{array}$ & $\begin{array}{l}\text { Positive effect on } \\
\text { employment and } \\
\text { earnings, no effect on } \\
\text { income, small or zero } \\
\text { effects on AFDC } \\
\text { participation }\end{array}$ \\
\hline Fein et al. (2001) & $\begin{array}{l}\text { Waiver program in } \\
\text { Delaware }\end{array}$ & $\begin{array}{l}\text { Employment, earnings, } \\
\text { income, AFDC } \\
\text { participation }\end{array}$ & $\begin{array}{l}\text { Randomized } \\
\text { assignment on } \\
\text { population of AFDC } \\
\text { recipients }\end{array}$ & $\begin{array}{l}\text { Positive effect on } \\
\text { employment and } \\
\text { earnings, no effect on } \\
\text { income or AFDC } \\
\text { participation }\end{array}$ \\
\hline Moffitt (1999) & $\begin{array}{l}\text { All state waiver } \\
\text { programs }\end{array}$ & $\begin{array}{l}\text { AFDC participation } \\
\text { rate, labor supply and } \\
\text { earnings of less } \\
\text { educated women }\end{array}$ & $\begin{array}{l}\text { Cross-state variation in } \\
\text { timing of waiver } \\
\text { introduction }\end{array}$ & $\begin{array}{l}\text { No effect on } \\
\text { employment or } \\
\text { earnings; positive } \\
\text { effect on weeks and } \\
\text { hours worked; negative } \\
\text { effect on AFDC } \\
\text { participation rate }\end{array}$ \\
\hline
\end{tabular}


Table 5 (continued)

\begin{tabular}{|c|c|c|c|c|}
\hline Study & $\begin{array}{l}\text { Program(s) } \\
\text { Studied }\end{array}$ & $\begin{array}{c}\text { Dependent } \\
\text { Variable }\end{array}$ & $\begin{array}{c}\text { Source of } \\
\text { Program Variation }\end{array}$ & $\begin{array}{l}\text { Estimated Effect } \\
\text { of Welfare Reform }\end{array}$ \\
\hline Mueser et al. (2000) & $\begin{array}{l}\text { Waiver programs in } \\
\text { five urban areas }\end{array}$ & $\begin{array}{l}\text { AFDC entry and exit } \\
\text { rates, employment rate } \\
\text { of welfare leavers }\end{array}$ & $\begin{array}{l}\text { Cross-state variation in } \\
\text { timing of waiver } \\
\text { introduction }\end{array}$ & $\begin{array}{l}\text { Negative effect on } \\
\text { entry rate, positive } \\
\text { effect on exit rate, } \\
\text { positive but small } \\
\text { effect on employment } \\
\text { rate of leavers }\end{array}$ \\
\hline O’Neill and Hill (2001) & $\begin{array}{l}\text { All state waiver } \\
\text { programs }\end{array}$ & $\begin{array}{l}\text { Employment, AFDC } \\
\text { participation }\end{array}$ & $\begin{array}{l}\text { Cross-state variation in } \\
\text { timing of waiver } \\
\text { introduction }\end{array}$ & $\begin{array}{l}\text { Positive on } \\
\text { employment, negative } \\
\text { on AFDC participation }\end{array}$ \\
\hline Schoeni and Blank (2000) & $\begin{array}{l}\text { All state waiver } \\
\text { programs }\end{array}$ & $\begin{array}{l}\text { Labor supply, } \\
\text { earnings,income, } \\
\text { AFDC participation }\end{array}$ & $\begin{array}{l}\text { Cross-state variation in } \\
\text { timing of waiver } \\
\text { introduction combined } \\
\text { with difference-in- } \\
\text { difference using high- } \\
\text { educated control group }\end{array}$ & $\begin{array}{l}\text { Positive effects on } \\
\text { labor supply, earnings, } \\
\text { income; negative } \\
\text { effects on AFDC } \\
\text { participation }\end{array}$ \\
\hline
\end{tabular}


Table 5 (continued)

\begin{tabular}{|c|c|c|c|c|}
\hline Study & $\begin{array}{l}\text { Program(s) } \\
\text { Studied }\end{array}$ & $\begin{array}{c}\text { Dependent } \\
\text { Variable }\end{array}$ & $\begin{array}{c}\text { Source of } \\
\text { Program Variation }\end{array}$ & $\begin{array}{l}\text { Estimated Effect } \\
\text { of Welfare Reform }\end{array}$ \\
\hline \multicolumn{5}{|l|}{$\underline{\text { TANF }}$} \\
\hline Ellwood (2000) & $--^{a}$ & Employment, earnings & $\begin{array}{l}\text { Difference-in- } \\
\text { difference with high- } \\
\text { wage control group }\end{array}$ & $\begin{array}{l}\text { Cannot separate effect } \\
\text { of EITC and welfare } \\
\text { reform }\end{array}$ \\
\hline McKernan et al. (2000) & $--^{\mathrm{a}}$ & Employment & $\begin{array}{l}\text { Difference-in- } \\
\text { difference with } \\
\text { childless women } \\
\text { control group }\end{array}$ & Positive \\
\hline O’Neill and Hill (2001) & $--^{a}$ & $\begin{array}{l}\text { Employment, AFDC- } \\
\text { TANF participation }\end{array}$ & $\begin{array}{l}\text { Cross-state variation in } \\
\text { timing of TANF } \\
\text { implementation }\end{array}$ & $\begin{array}{l}\text { Positive on } \\
\text { employment, negative } \\
\text { on AFDC-TANF } \\
\text { participation }\end{array}$ \\
\hline Schoeni and Blank (2000) & $--^{\mathrm{a}}$ & $\begin{array}{l}\text { Labor supply, } \\
\text { earnings,income, } \\
\text { AFDC-TANF } \\
\text { participation }\end{array}$ & $\begin{array}{l}\text { Difference-in- } \\
\text { difference with high- } \\
\text { educated control group }\end{array}$ & $\begin{array}{l}\text { No effect on labor } \\
\text { supply or individual } \\
\text { earnings, positive } \\
\text { effect on family } \\
\text { earnings and income, } \\
\text { negative effect on } \\
\text { AFDC-TANF } \\
\text { participation }\end{array}$ \\
\hline
\end{tabular}

Notes:

${ }^{a}$ All TANF. 


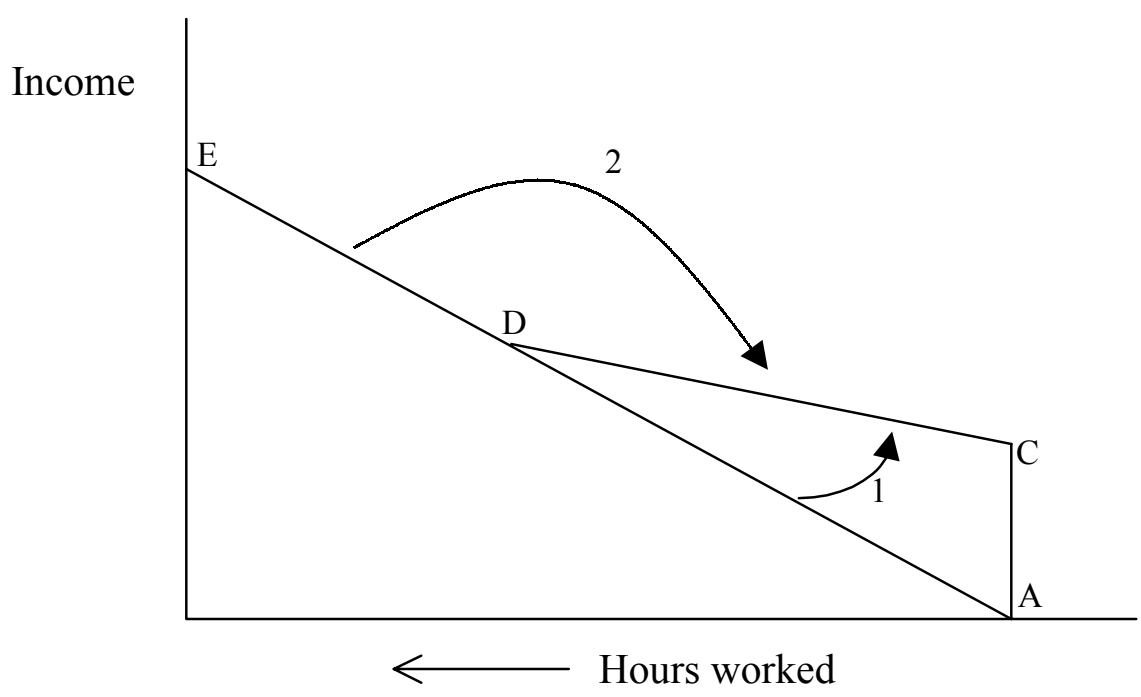

Figure 1. Generic Welfare Program

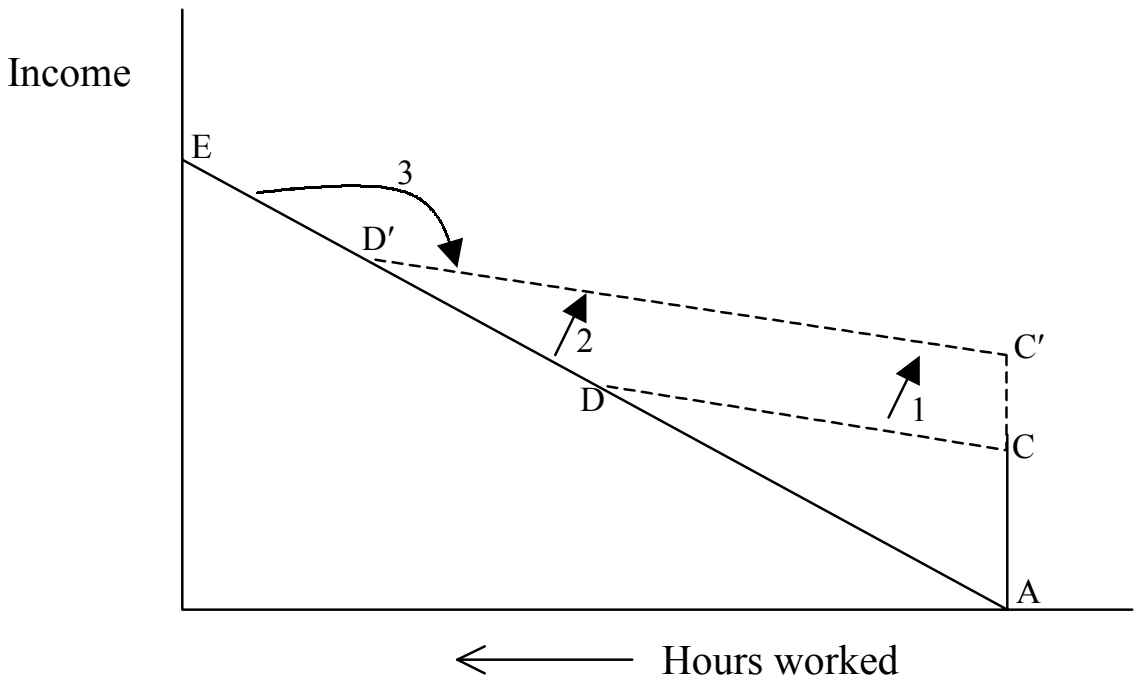

Figure 2. Effect of an Increase in $\mathrm{G}$ 


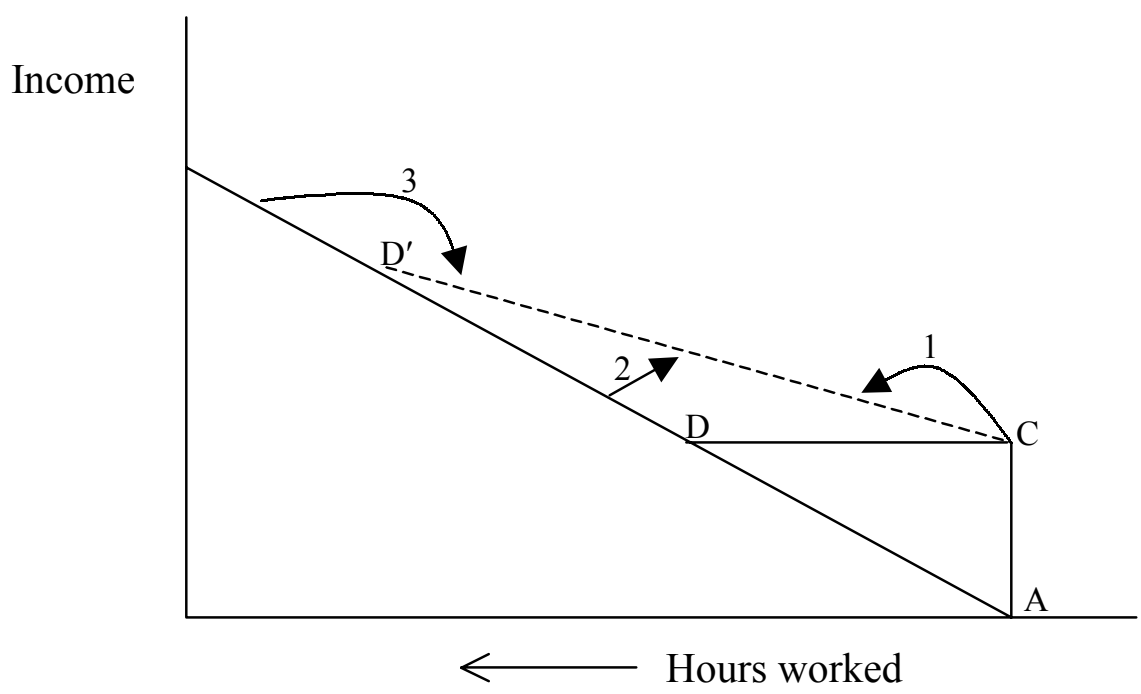

Figure 3. Effect of a Decrease in $t$

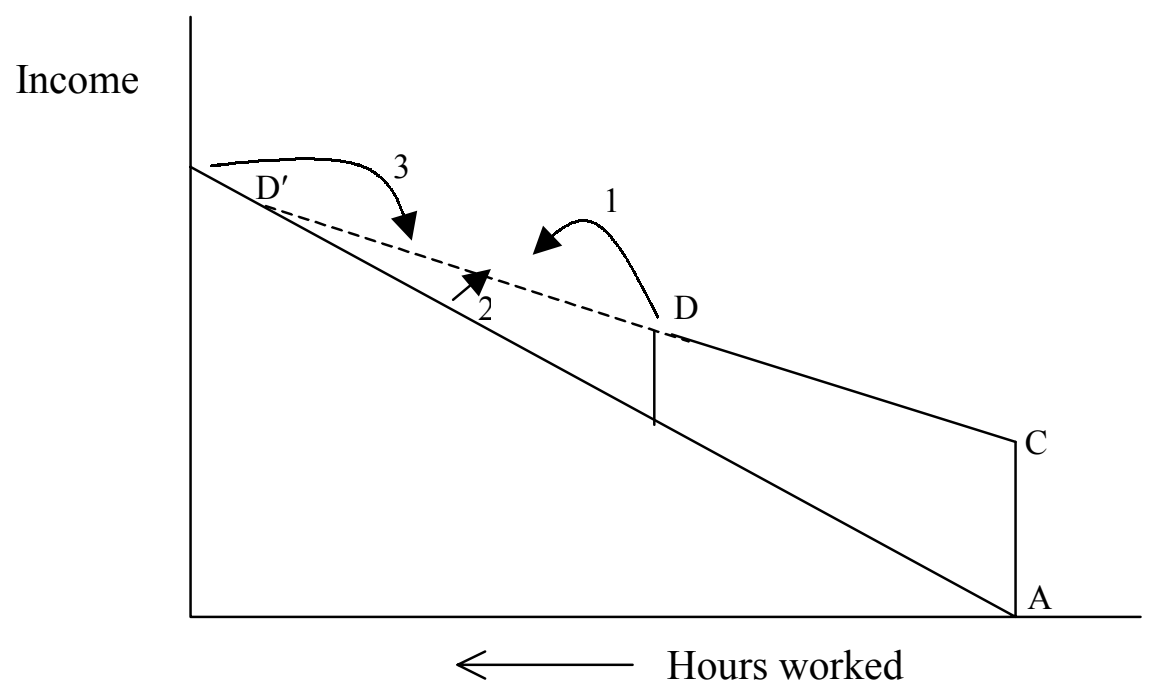

Figure 4. Welfare Program with a Notch 


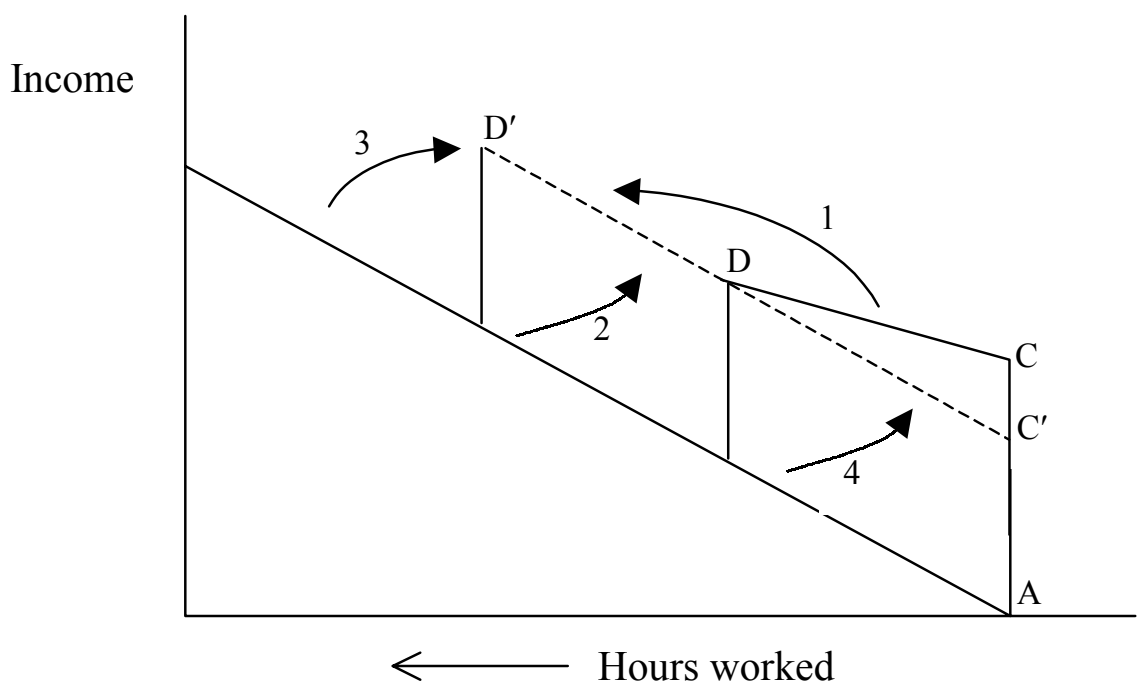

Figure 5. Medicaid Expansion

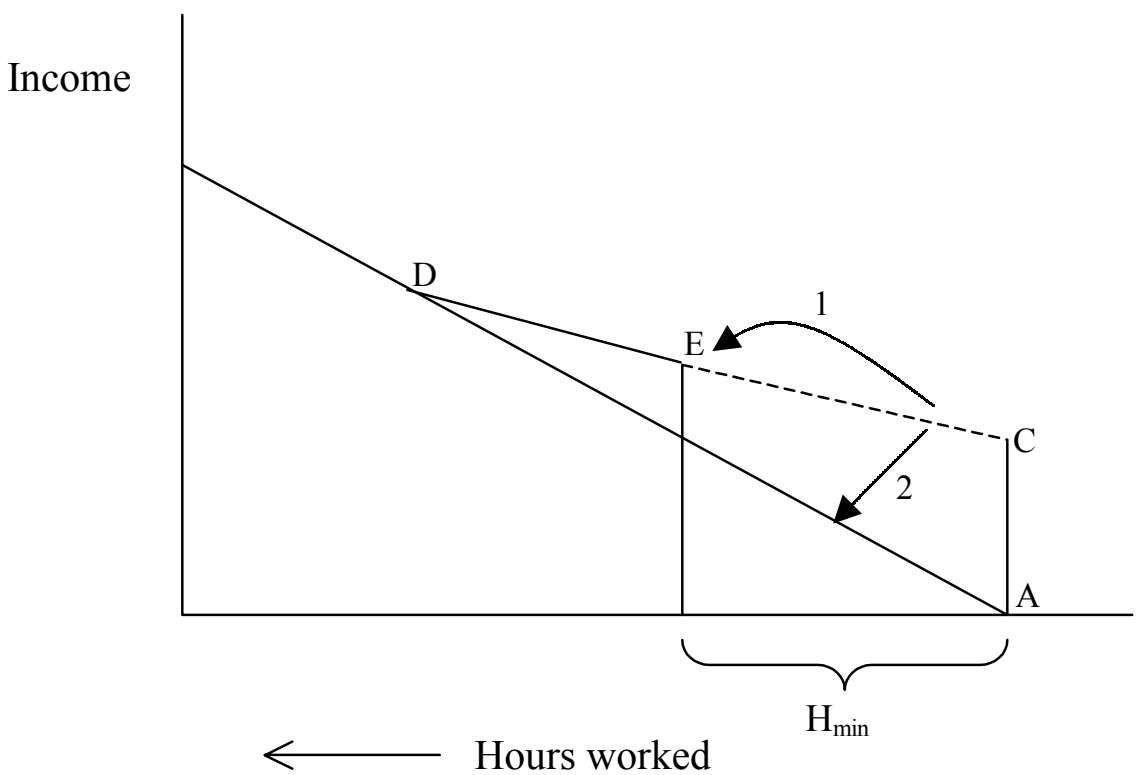

Figure 6. Work Requirement 


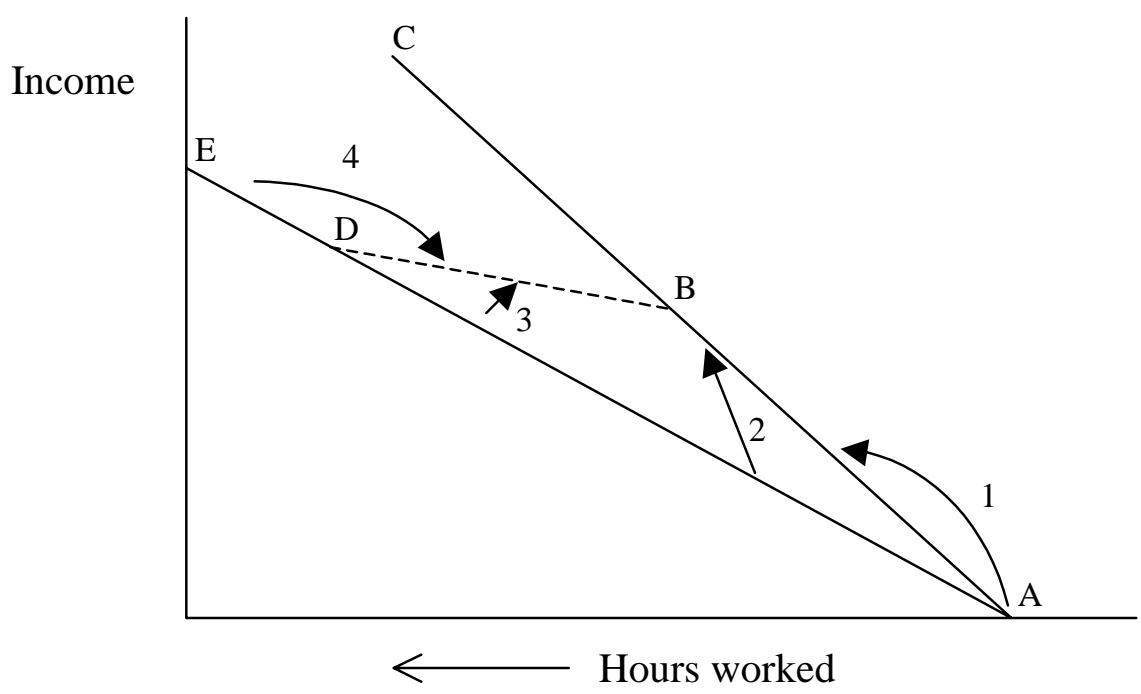

Figure 7. Earnings and Wage Subsidies

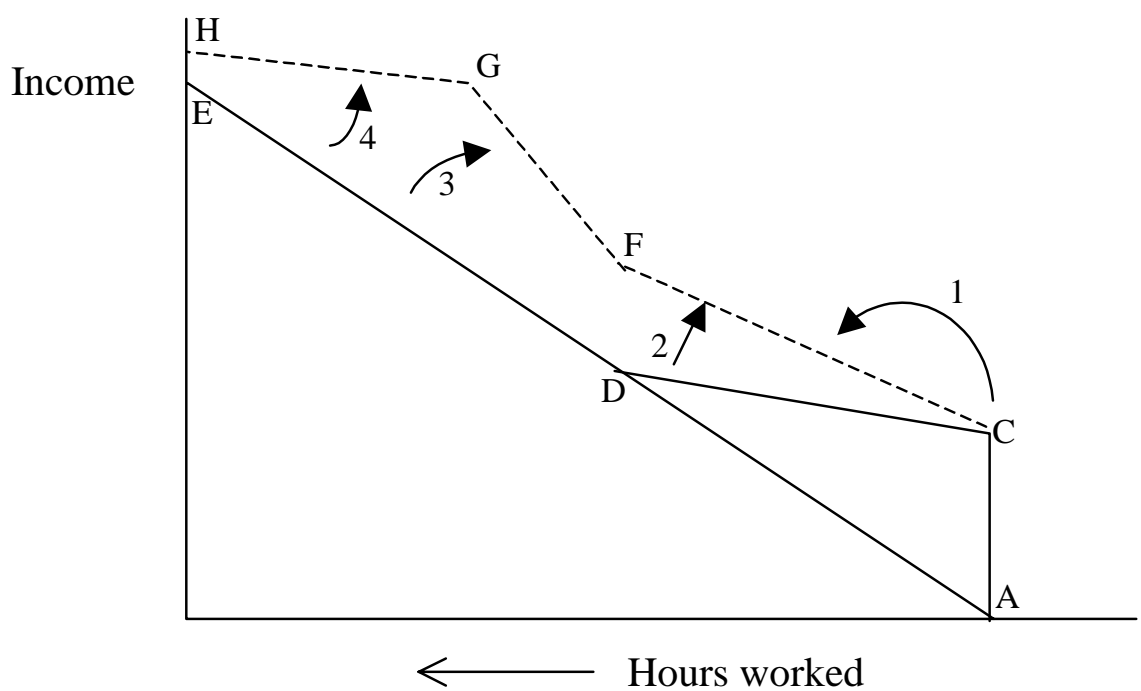

Figure 8. Earnings Subsidy Plus Welfare Program 


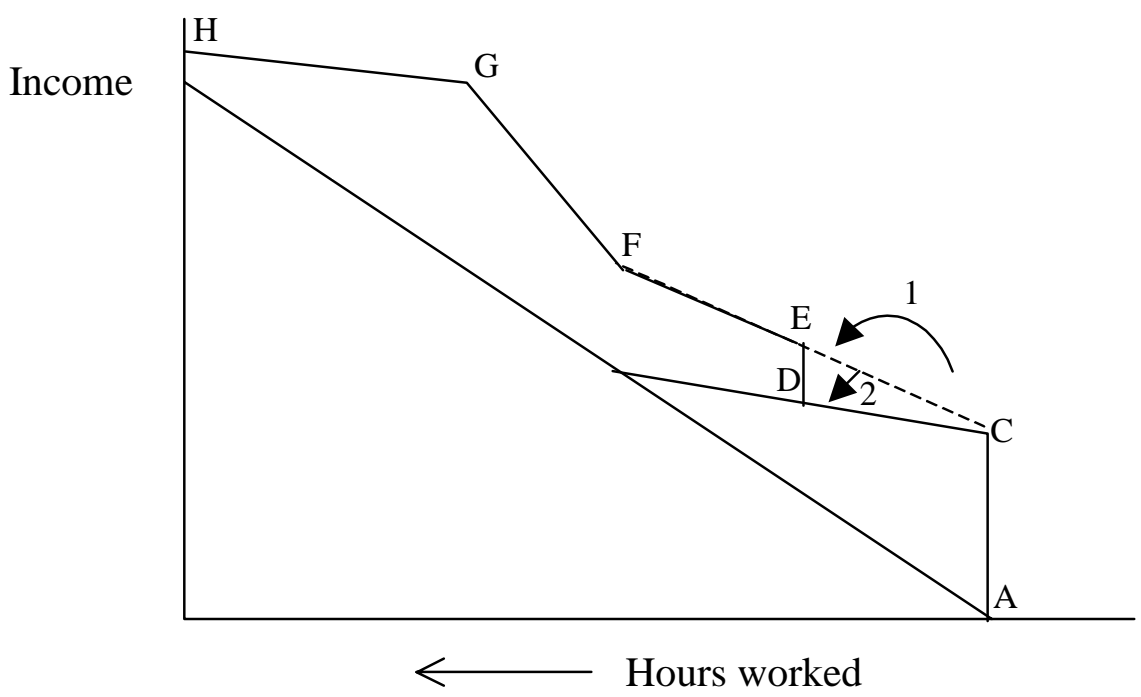

Figure 9. Earnings Subsidy with a Work Requirement Plus Welfare Program 